\title{
Euratom
}
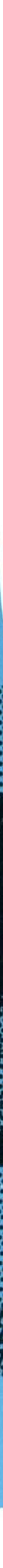
The Ispra Research Establishment, Italy.

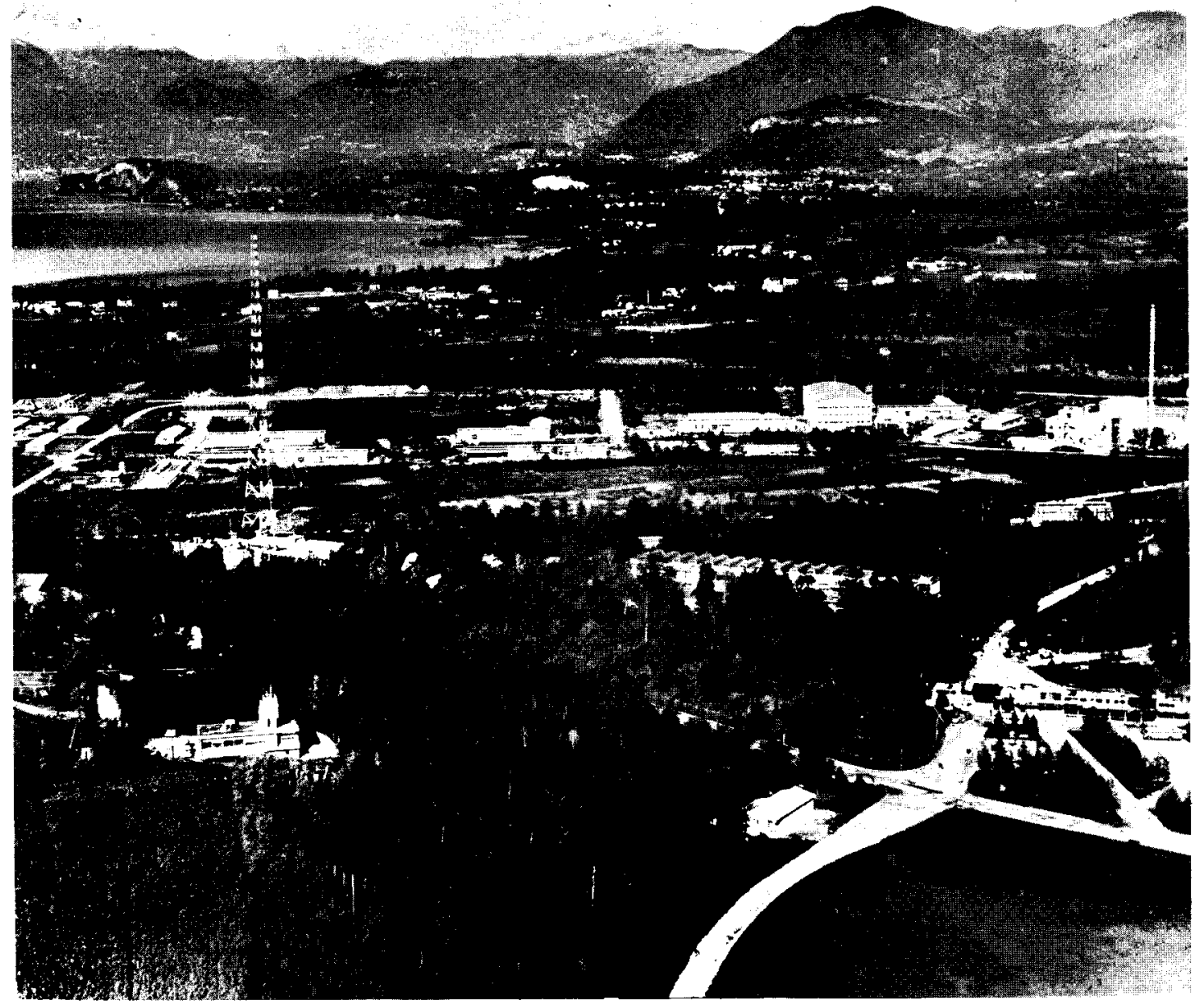




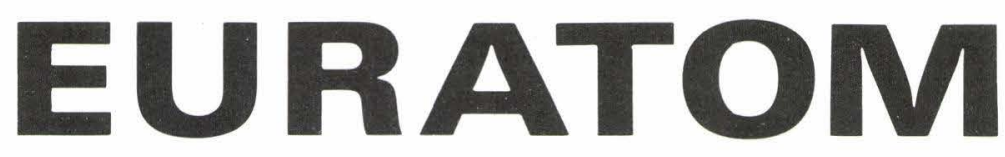

\section{The European Atomic Energy Community}

Official Spokesman, Euratom Commission

European Community Press and Information Service 


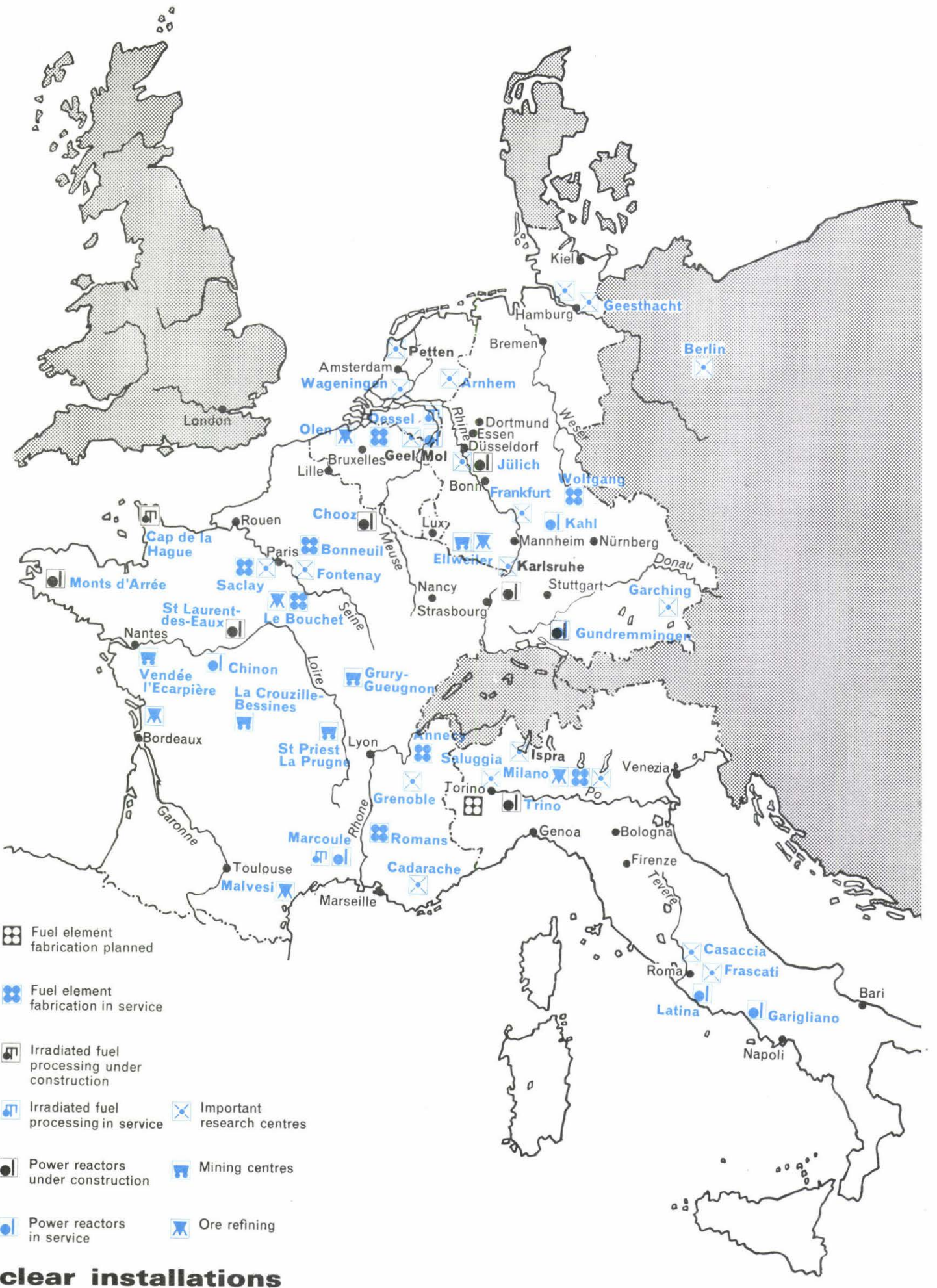

Nuclear installations

in the

European Community 


\section{Contents}

Map of the Community's nuclear installations 2

Euratom - spearhead of the Community's atomic revolution 4

How it started 6

Why a combined effort is needed 7

The task - an atomic industry for 170 million Europeans 8

How Euratom works 10

How much nuclear power? 12

$\begin{array}{ll}\text { The production of nuclear power } & 14\end{array}$

Second Euratom research program launched 16

$\begin{array}{ll}\text { Joint research in Euratom centres } & 17\end{array}$

$\begin{array}{ll}\text { Some of the subjects of reactor research } & 18\end{array}$

In quest of economic reactors 18

$\begin{array}{ll}\text { International research projects } & 19\end{array}$

Bilateral agreements $\quad 22$

Radiation and isotopes at work $\quad 24$

Pooling the results of research 25

The Supply Agency 26

Euratom's inspectors $\quad 26$

The nuclear common market 26

$\begin{array}{ll}\text { Safeguards against radiation } & 27\end{array}$

Nuclear insurance 28

The European Schools 28

Two revolutions in one 30 


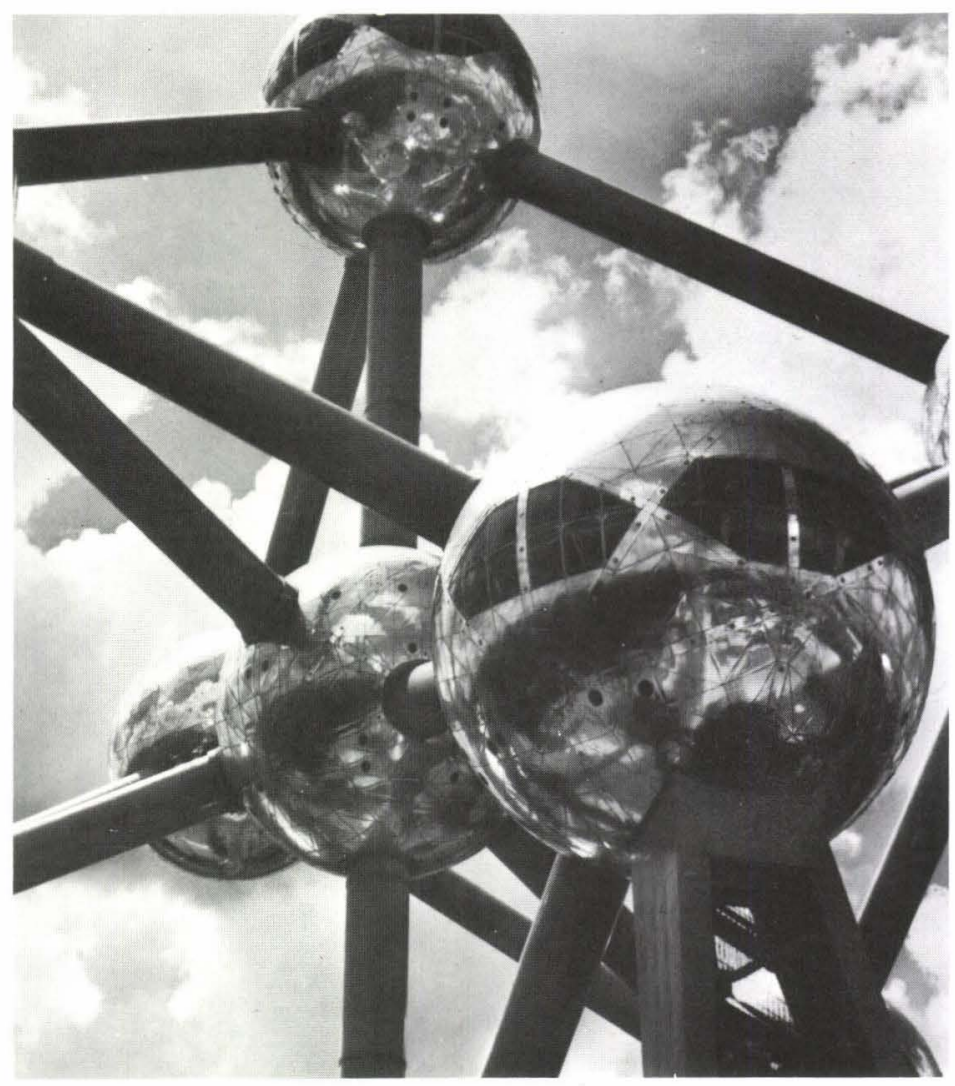

EURATOM

spearhead of the Community's atomic revolution

Energy is the key to modern industrial development. Without the energy provided by coal, water-power, oil and natural gas, the wheels of industry would stop turning, our prosperous cities and countryside fall into decay, and living standards shrink to a fraction of present levels. We should be back in the era of manpower and horse-power - provided, not by machines, but by men and horses.
The Atomium, built as the central motif of the Brussels World Exhibition in 1958; it now houses a permanent Euratom exhibition. 
Estimated expenditure on nuclear research per head of population, 1961 (in \$)

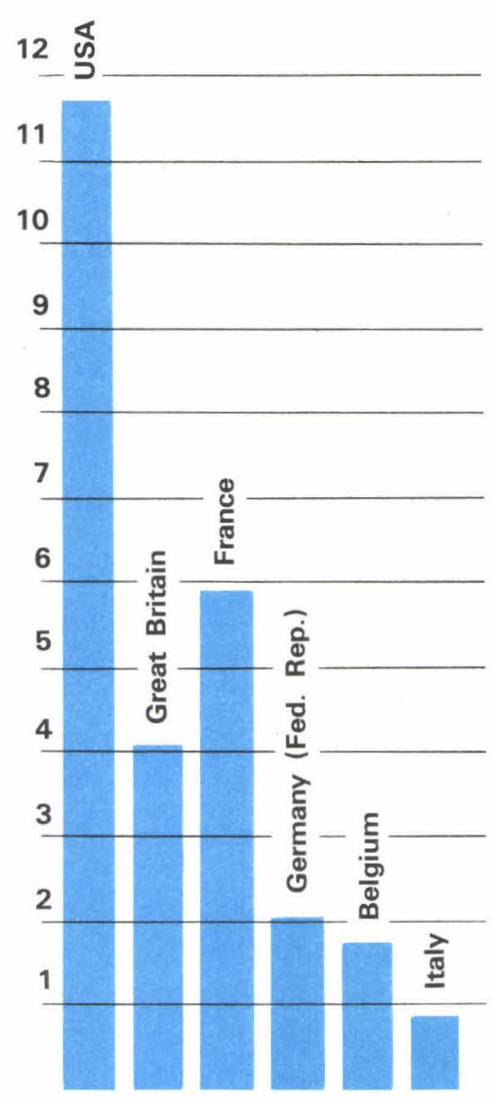

Over the next twenty years, the six countries of the European Community - Belgium, France, Germany, Italy, Luxembourg and the Netherlands - are likely to. double their gross national income. The expansion of industrial production will be much greater even than that. Electricity consumption is doubling every ten years so that by 1980 it will be four times the 1960 level.

There is no guarantee that supplies of coal, waterpower, oil and natural gas - the conventional sources of energy - will be able to keep pace with this startling expansion in the needs of industry. Present indications are that adequate amounts of conventional energy could be found to meet these mounting needs, but only by increasing the Community's dependence on foreign supplies and placing a tremendous burden on the Community's import bill.

A revolutionary new source of energy has been discovered. Atomic energy - the result of half-acentury of patient research into the very core of matter by European and American scientists - offers mankind tremendous new possibilities. So far its main potential lies in the production of electricity. But atomic energy is still in its initial stages.

The United States, which in 1958 produced more than three times as much electricity as the Community, and Russia, which produced roughly the same amount as the Community, are both spending many thousands of millions of dollars to achieve economic production of nuclear electricity. Britain is straining her resources for the same purpose.

The countries of Western Europe could not be left behind in this second industrial revolution which atomic power will bring. The essential task was to unite their resources in an all-out effort.

Just as the Common Market is an attempt. to spur rapid economic growth and industrial strength, in an age of continental economic powers, so Euratom - the European Atomic Energy Community - represents an effort to guide the Community forward surely and confidently into the atomic age. For the Community's 175 million inhabitants, Euratom will help fashion the new industrial revolution. 


\section{How it started}

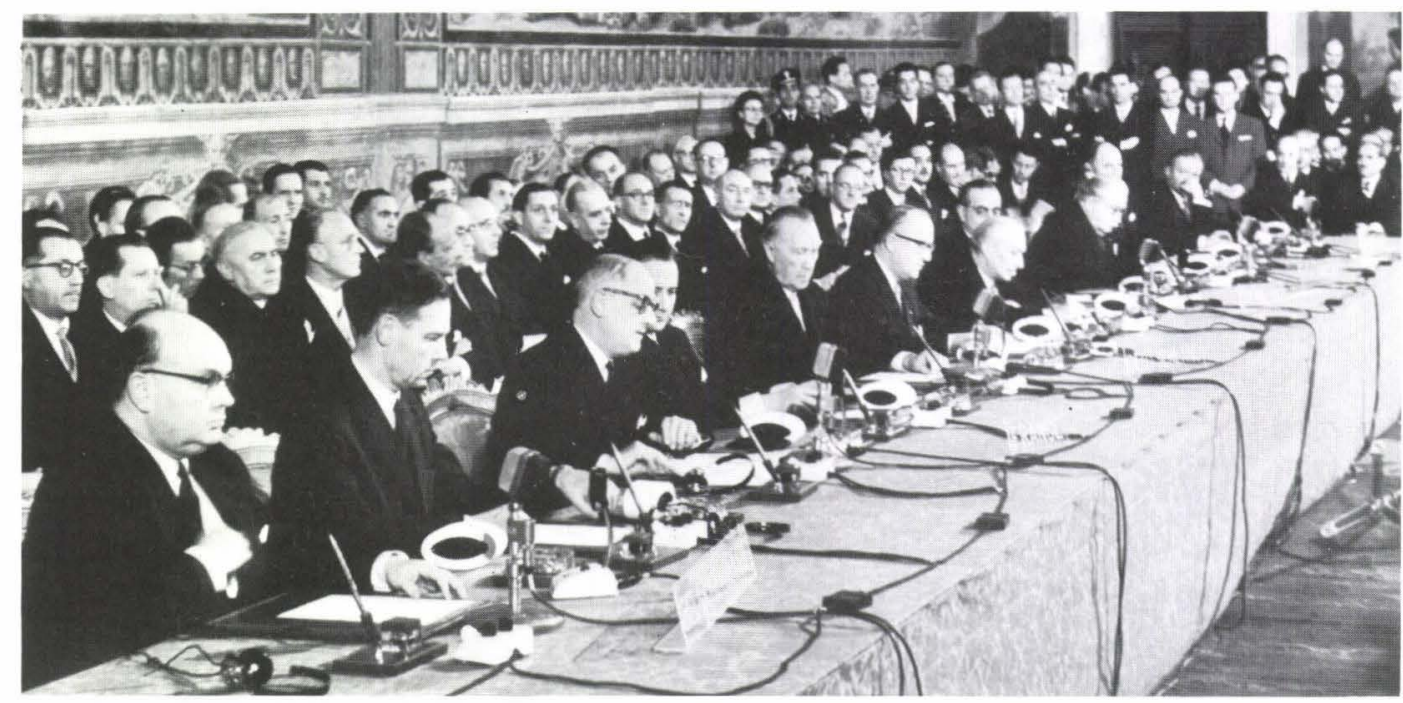

Signature of the Common Market and Euratom Treaties in the Hall of the Conservators on the Capitoline Hill, Rome, March 25, 1957.

\section{0}

Euratom is one of the three pillars of the movement towards Western European unity that began with the Schuman declaration of May 9, 1950. On that date Robert Schuman, then French Foreign Minister, proposed that the coal and steel industries of France and Germany and other Western European countries be placed under a common High Authority to which the governments would transfer sovereign powers. On April 18, 1951, the six countries signed a Treaty setting up the European Coal and Steel Community (ECSC). The first step towards European economic and political unity had been taken.

\section{7}

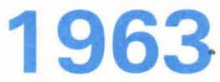

Six years later, on March 25, 1957, the same six countries signed the Rome Treaties establishing the European Economic Community (Common Market) and the European Atomic Energy Community (Euratom). The treaties came into force on January 1, 1958.

Together, Euratom, the ECSC and the Common Market are now establishing, through common institutions, a vast home market for all industrial and agricultural products, and common economic policies.

Their aims are twofold:

to put the Community on the same economic footing for expansion and low-cost production as the USA and the USSR; to achieve full unity, so that the European countries may again play a full part in world affairs and, in particular, in aiding the less-favoured countries of the world in their economic development. 


\section{Why a combined effort is needed}

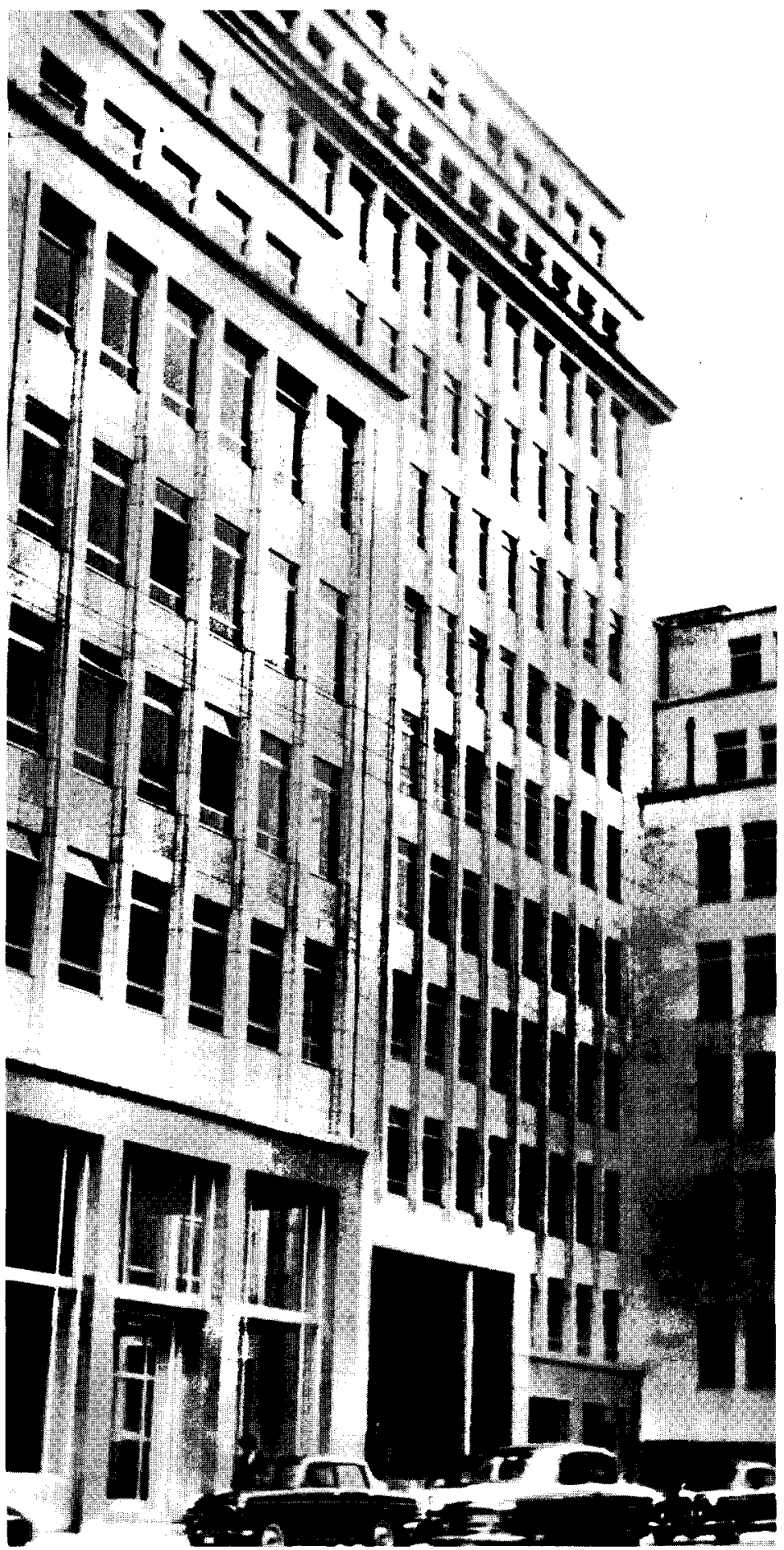

Recent forecasts indicate that, by 1980 . one-quarter of the Community's electricity needs - an amount roughly equal to the Community's total electricity consumption at present will have to be supplied by nuclear power stations.

Even the larger Community countries could only with enormous difficulty provide the financial and technical resources sufficient to build a nuclear industry of this size. For the smaller countries, going it alone is impossible. And for all countries, both large and small, atomic power makes frontiers out of date.

Uncoordinated individual research and development programs are wasteful because. among other things:

nuclear research is extremely expensive and the maximum use must be made of the available financial resources;

trained scientists and technicians are still too few to permit an absence of coordination of national efforts:

health and safety rules must be uniform and universally applied in an area as small as Western Europe.

Unlike the ECSC and the Common Market, which have had to start by breaking down long-established barriers between the member states. Euratom has had few existing barriers to demolish. Instead of welding together six existing industries, Euratom must spur the development of a new atomic industry for the united Europe of the future.

Headquarters of the

Euratom Commission,

rue Belliard, Brussels. 


\section{The task an atomic industry}

\section{for 175 million Europeans}

'It shall be the aim of the Community to contribute to the raising of the standard of living in member states and to the development of commercial exchanges with other countries by the creation of conditions necessary for the speedy establishment and growth of nuclear industries' (Article I of the Euratom Treaty)

The British-built natural uranium reactor now in service at Latina, south of Rome.
The European nuclear industry which Euratom is called on to bring into being must, in addition, be concerned solely with the peaceful uses of atomic energy, under the terms of the Treaty.

In 1958, although a number of research reactors and other installations were already in existence in the other countries, France was the only country which had developed nuclear power to any extent. Euratom must ensure that the Community as a whole gets the nuclear power which will be required on an increasingly large scale from the end of the present decade.

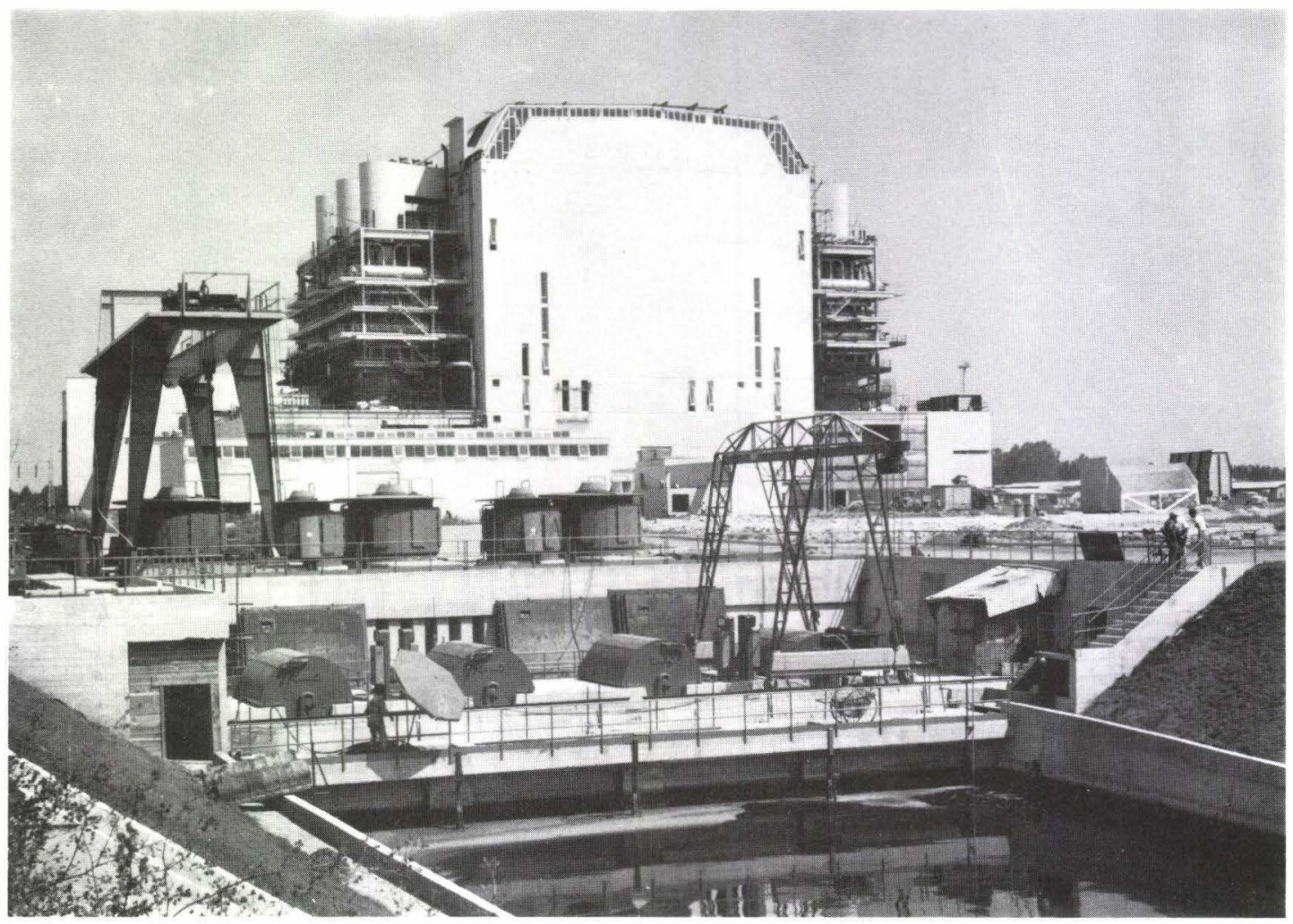




\section{Building a nuclear \\ industry}

Research for high efficiency, low costs
Euratom must

facilitate investment in nuclear power production and ensure, particularly by encouraging individual enterprises, the construction of the key installations needed;

encourage secondary utilizations of atomic energy, such as the exploitation of radioisotopes and radioelements, which have a vital and growing role to play in agriculture, medicine and industry.

Euratom must develop research and assure the widest possible dissemination of technical knowledge. The primary aim of research is to enable nuclear energy to be produced as cheaply as possible. The Community therefore needs experience of a number of different reactor systems; Euratom must broaden this experience, both through research within the Community and through cooperation with other countries and with international organizations.

Euratom takes over the role of governments or national authorities as regards supplies. It must see that all consumers in the Community are regularly and equitably supplied with ores and fissile materials. Over special fissile materials it exercises full rights of ownership. And it must exercise appropriate controls to prevent nuclear materials from being diverted from their declared purposes.

Euratom must ensure that national barriers do not impede the development of a Community atomic industry. It has therefore established a common market for nuclear materials and equipment and ensures the free circulation of capital for atomic investment and freedom for technicians to work anywhere in the Community.
For health protection and safety
A nuclear industry could be a threat to public health if not kept under stringent control. Euratom must therefore ensure that the basic standards for health protection and safety, which it has drawn up, are applied by the member states. 


\section{How Euratom works}

\section{The Commission}

The Euratom Commission is the executive body responsible for carrying out the Euratom Treaty. It is the mainspring of the Community, preparing proposals on which the Council of Ministers takes decisions, keeping a day-to-day watch on all aspects of the Community's work and planning its future development. The Commission consists of five members, independent of national governments and sectional interests; it takes its decisions in the interest of the Community as a whole, and is answerable to the European Parliament. It has close links with the Executives of the other two Communities and cooperates closely with them in much of its day-to-day work.

The five members of the Commission are:

President: Pierre Chatenet (French)

Vice-President: Prof. Enrico Medi (Italian)

Members: Paul-Hubert de Groote (Belgian)

Heinz Krekeler (German)

Emanuel M. J. A. Sassen (Dutch)

\section{The Council of Ministers}

The Council ensures co-ordination between national policies and the policy of the Community. It is the only Community institution whose members are representatives of national governments: a member of each government attends its meetings. It is usually the Council that takes the final decisions, but it can only do so on proposals from the Commission, and the latter's proposals can only be modified by unanimous vote. Most Council decisions are taken in unanimity, but in some cases a weighted majority vote is employed.

\section{Consultative bodies}

In addition, Euratom's work is aided by:

The Scientific and Technical Committee of 20 experts (scientists and leaders of the atomic industry), which advises the Commission on scientific and technical problems.

The Economic and Social Committee of 101 members, representing all sides of the Community's economic and social life: producers, consumers, business interests, workers and the professions. One section specializes in nuclear problems. This Committee serves both Euratom and the Common Market and acts as a consultative body for the Commissions and the Councils.

The Consultative Committee for Research, which has been set up by the Council to bring together national experts and members of the Commission to discuss the Community research program. It meets under the chairmanship of the Commission's President.

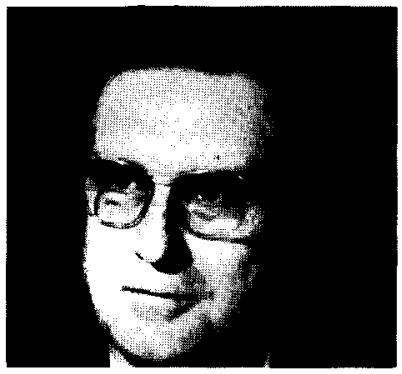

Commission President

Pierre Chatenet (French)

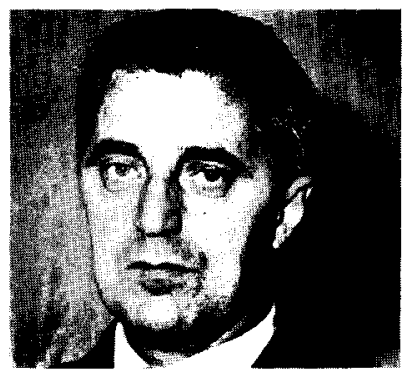

Commission Vice-President Prof. Enrico Medi (Italian)

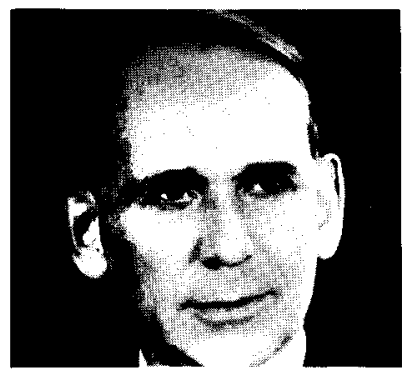

Commissioner

Paul-Hubert de Groote (Belgian)

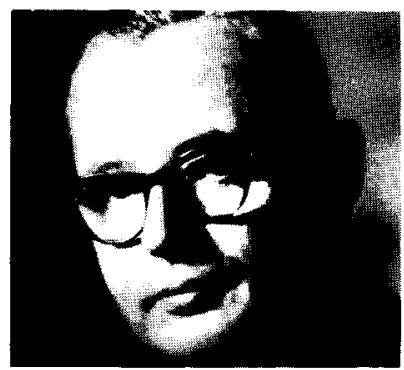

Commissioner Heinz Krekeler (German) 


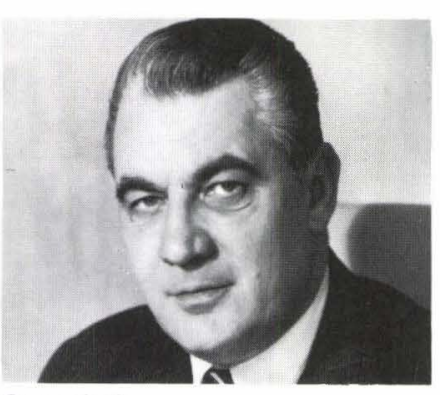

Commissioner

Emanuel Sassen (Dutch)

\section{The European Parliament}

The 142-member Community Parliament, which at present meets in Strasbourg, exercises democratic supervision over Euratom, the ECSC and the Common Market. Its members are at present appointed by and from the parliaments of member countries, but plans for direct elections are under discussion. The members sit in the Chamber in three main political groups (Christian Democrat, Socialist and Liberal).

The Commission must report annually to the Parliament, which can remove it from office on a vote of censure, passed by a twothirds majority. The Parliament must be consulted before certain specific decisions are taken and it has the right to scrutinize Euratom's budget. It meets in plenary session at frequent intervals and maintains thirteen standing committees.

\section{The Court of Justice}

The Court of Justice, the guardian of the Treaties, ensures the 'observance of law and justice in the interpretation and application' of the Community Treaties. Its seven judges, who sit in Luxembourg, have sole power to uphold or annul decisions of the Executives. Their judgments are binding on all parties, including individuals, firms, national governments and the Executives themselves.

\section{Community Institutions}

ECSC

European Coal and Steel Community

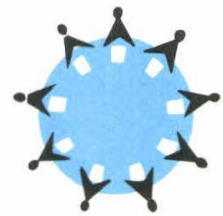

HIGH AUTHORITY

Consultative

Committee

\section{COMMON MARKET}

European Economic Community
EURATOM

European Atomic Energy Community

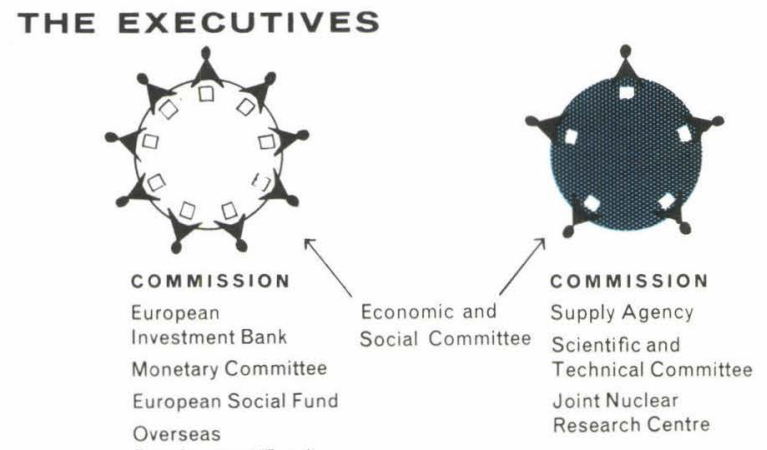

Development Fund

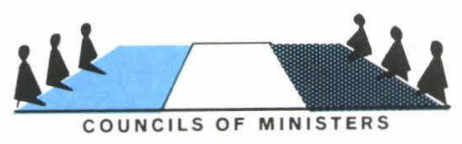

DEMOCRATIC CONTROL

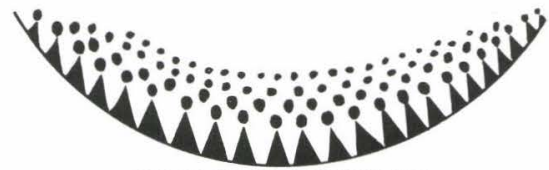

EUROPEAN PARLIAMEN
JUDICIAL CONTROL

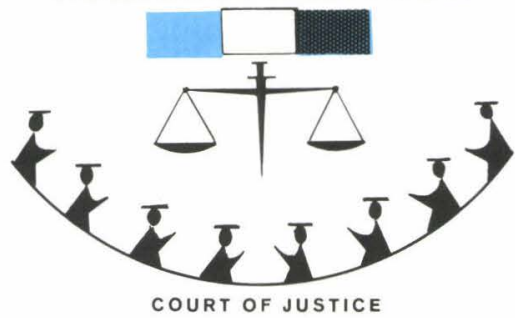


How

\section{much}

nuclear

power?
To-day there seems to be enough power. Coal mines are being closed and many new deposits of oil and natural gas have been recently discovered all over the world. But to-day's plentiful supplies should not obscure the rapid annual increase in demand.

\section{Rising power} needs
In the Community, total industrial production has been rising at the phenomenal average rate of about $82 \%$ a year in the fifties: using as a basis of calculation the conservative assumption that it will rise by $5 \%$ a year in the sixties and $4 \%$ in the seventies, the three Communities' Working Group on Energy has forecast a substantial expansion in the Community's power needs over the next 20 years (see graph on facing page).

In the expansion in energy requirements, electricity will play a predominant part. The graph shows that, while total power requirements are expected to double in 15 years, electricity needs will expand much more rapidly: nearly four times as much will be needed in 1980 as in 1960 . The great energy problem of the next twenty years is to decide how to meet these rapidly rising needs, and, above all, which source of energy can best meet the Community's needs.

Coal will certainly retain an important share, but pit closures and high stocks are ample evidence that the proportion of coal which can be produced at economic, competitive prices is falling rather than rising, and the share of oil in industry's total power supply is constantly increasing. The amount of water power available is strictly limited.

One way out would be to meet increased needs by oil and natural gas. The great disadvantage of such a solution is that Community sources of these forms of energy are strictly limited; by far the greater part of her oil needs is supplied by imports.

Already about $35 \%$ of all energy consumed in the Community is imported, at a total annual cost of nearly $\$ 3,000$ million. By 1975, without nuclear power this proportion would exceed $50 \%$. Unless nuclear power can be produced cheaply enough, the Community would risk a trebling of its fuel import bill between 1960 and 1980 . 
Everything will therefore depend on the cost of nuclear power. Euratom forecasts that nuclear power stations will be competitive in many areas of the Community between 1965 and 1967 and in the Community as a whole towards 1968-70. Power stations now being built, moreover, are 'on the threshold of competitivity' (Sixth General Report of the Commission). Breeder and other advanced reactor types being developed hold promise of further reductions in power costs in the early 1970s.

A tentative timetable for nuclear power

Rising energy needs

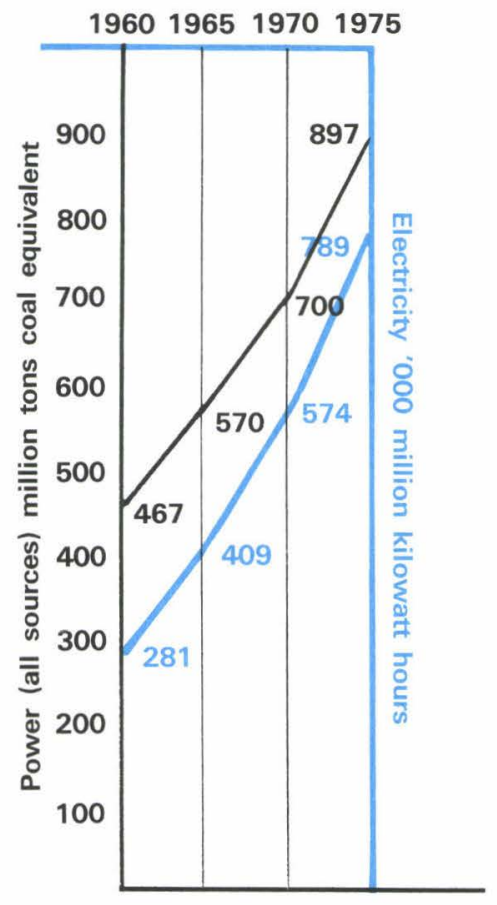

Euratom's policy for the present is not to undertake a largescale nuclear power-station program, as conventional fuel sources are more than adequate. Instead, a limited number of full-size power-stations of a number of different types are being built.* By the end of 1965, total capacity should be about 2,000 megawatts $(\mathrm{mW})$ - equal to about ten middle-sized power-stations. But by 1980 , nuclear power capacity may have to be as much as $40,000 \mathrm{~mW} \dagger$ - twenty times as much - if expected power needs are to be met.

\footnotetext{
* About $2,000 \mathrm{~mW}$ of capacity had been authorized or was under construction in May, 1963.

+1 megawatt $(\mathrm{mW})=1,000$ kilowatts $(\mathrm{kW})$

1 kilowatt $(\mathrm{kW})=1,000$ watts.
}

Theoretically $1 \mathrm{~mW}$ of power capacity will produce 1 (megawatt) $\times 24$ (hours) $\times 365$ (days) = 8,760 megawatt-hours $(\mathrm{mWh})$ a year. In practical calculations, the degree of utilization of this theoretical capacity - the load factor - is taken generally as $80 \%$. Therefore, $40,000 \mathrm{~mW}$ of capacity will produce $40,000 \times 80 / 100 \times 8,760=280,320,000$ megawatt-hours $(\mathrm{mWh})$ per year.

Electricity consumption per head of population, 1961

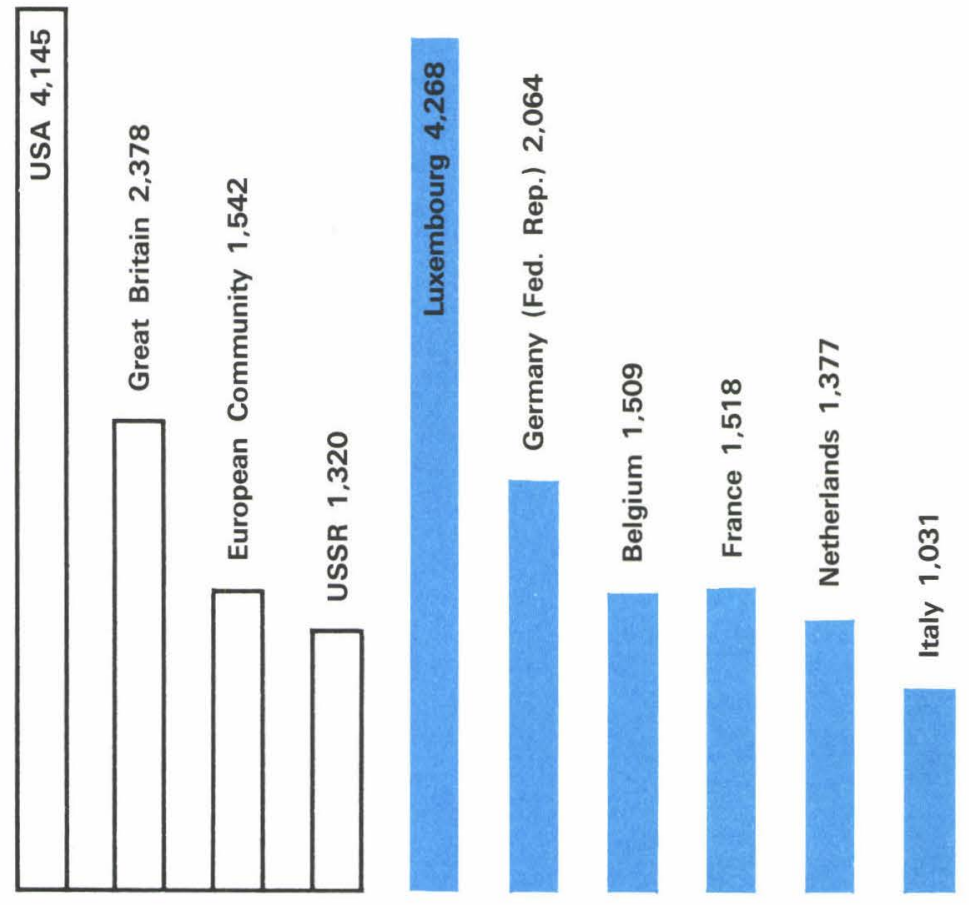




\section{The production of nuclear power}

The production of nuclear electricity is theoretically a very simple process. An atomic reactor produces heat from the controlled disintegration of its fuel: it is the equivalent of a conventional furnace, but with coal or gas replaced by uranium in varying degrees of enrichment. The heat produced has to be harnessed to the operation of a turbine which in turn produces electricity or, to take another example, operates the propeller of a ship.

But many practical difficulties must be overcome; reactors, machinery and materials must be tested and proved and technicians and experts trained. Euratom's task is not to build power-stations; this is the job of private or public organizations. Euratom's role is to encourage and help them to do so:

by contributing to the knowledge of power reactor technology: by providing investment aid and otherwise assisting in the construction of nuclear power-stations;

by publishing periodically programs showing production targets for nuclear energy and the types of investment required in order to meet them.

Aerial view of the reactors at Chinon, France.

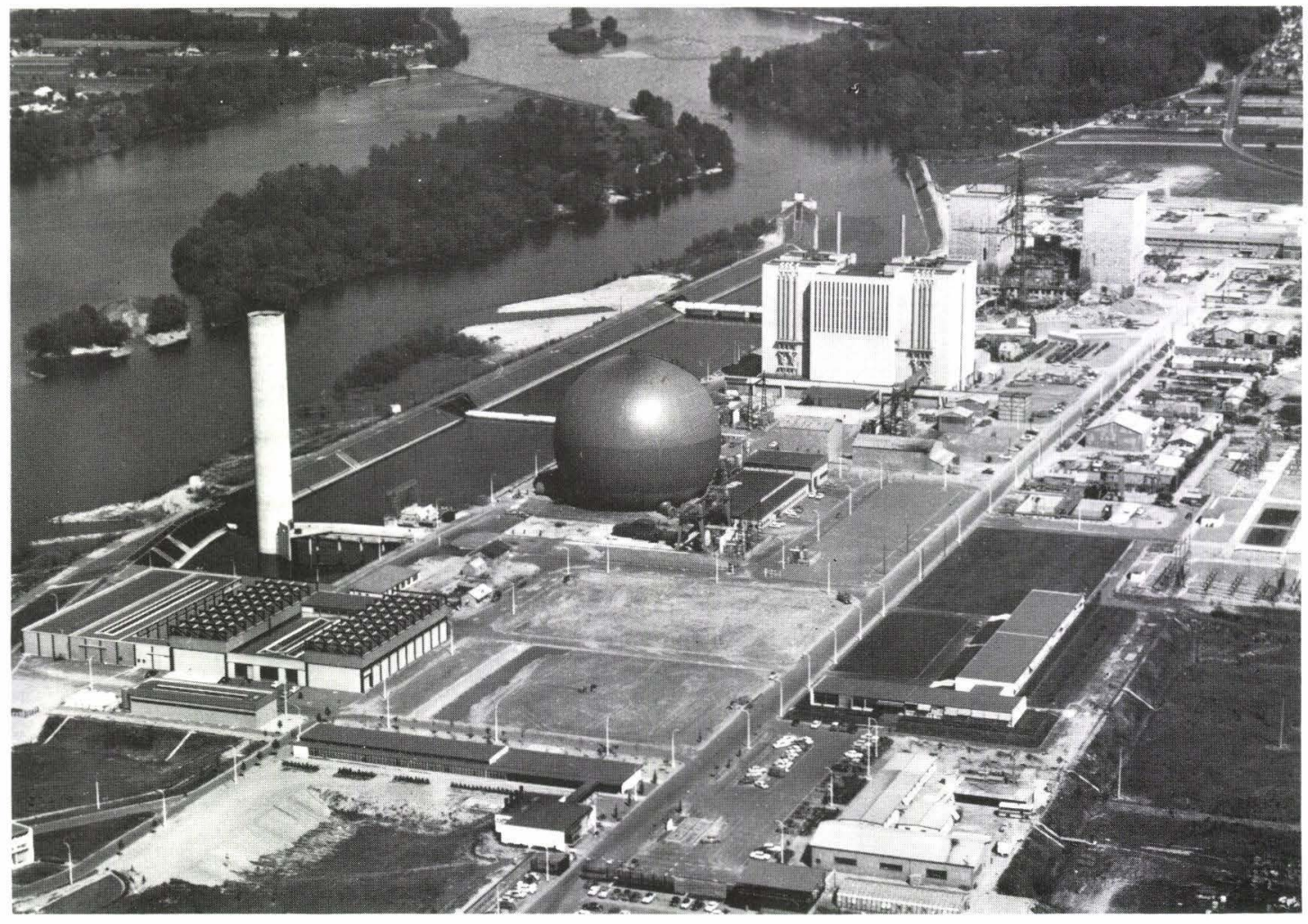


For the latter purpose, firms and other bodies must keep Euratom informed of their investment plans in all sections of the industry.

The Senn project: the $150 \mathrm{~mW}$ power reactor on the Garigliano river north of Naples.

\section{Aid to nuclear} power stations

\section{Outlook for the} future

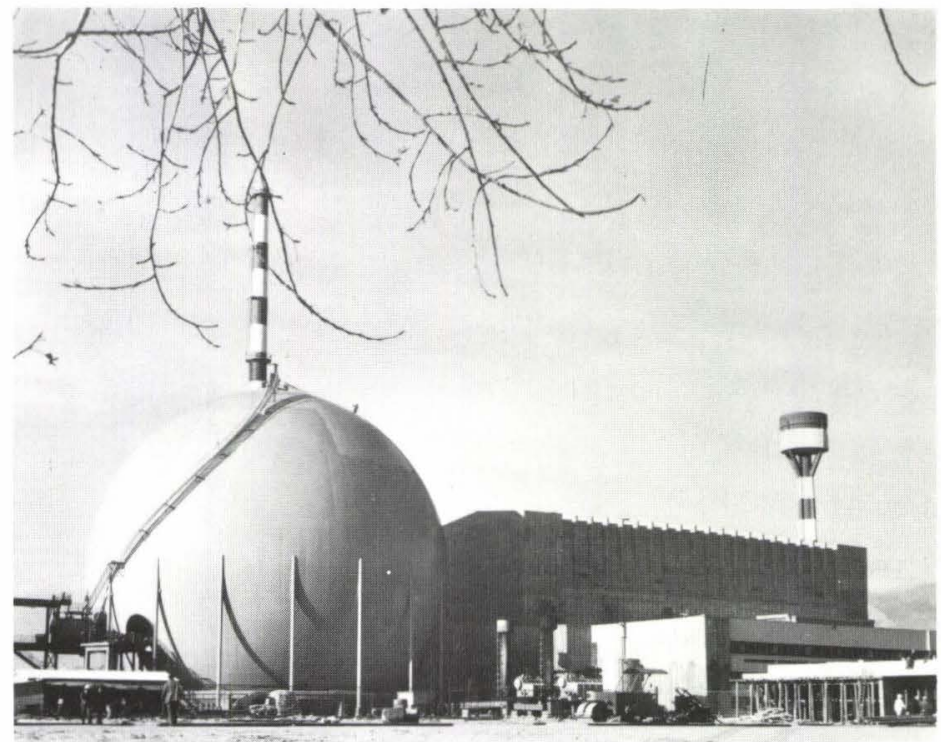

Euratom is encouraging power station construction in a number of ways. The US-Euratom Agreement, signed in November, 1958, provides for a joint power and research program. Three reactors, totalling around $700 \mathrm{~mW}$ of generating capacity and of types developed in the USA are being built, in two cases with the aid of US financial loans. They are the Italian SENN $150 \mathrm{~mW}$ project on the Garigliano river near Naples, the Franco-Belgian SENA group's $242 \mathrm{~mW}$ project at Chooz in the French Ardennes, and the German KRB group's $237 \mathrm{~mW}$ plant on the Danube at Gundremmingen, near UIm. SENN will be in operation before the end of 1963 and SENA and KRB by the end of 1965.

Euratom is allocating $\$ 32$ million to five power reactor projects, including the three mentioned above, which are likely to yield information of interest to other Community power reactor constructors and operators. In return for grants towards 'start-up' and initial fuel charge costs, constructional and operational 'know-how' is being put at the disposal of the Commission and so of the Community. Certain projects can also be declared a 'Joint Enterprise' and so benefit from certain taxation, tariff and other privileges. The Chooz plant was the Community's first Joint Enterprise, and has been followed by the KRB project.

By the end of 1962, the Community's nuclear electricity generating capacity stood at only $174 \mathrm{~mW}$, of which $149 \mathrm{~mW}$ was in France. By 1967, however, present plans point to 2,500-2,800 $\mathrm{mW}$ (the equivalent of ten medium-sized power stations) and the forecast is $3,500-4,000 \mathrm{~mW}$ for 1970 . But until nuclear power becomes truly competitive, the urgency is for experience and 'know-how' so that the Community will have sufficient operating experience to construct and run nuclear power stations on a large scale once the 'nuclear break-through' takes place. 


\section{Second Euratom research}

Although scientists from the Euratom countries made many of the basic discoveries which introduced nuclear power, until recently the Euratom countries were lagging behind the USA, the USSR and Great Britain in its development. Now the Community is quickly making up for lost time by complementing and co-ordinating research and intensifying the training of the scientists and technicians who will be needed for the atomic industry of the seventies. The foundations of the atomic industry of the future are now being laid.

Euratom has now embarked on its Second Five-Year Research Program (1963-67) for which it has $\$ 425$ million at its disposal.

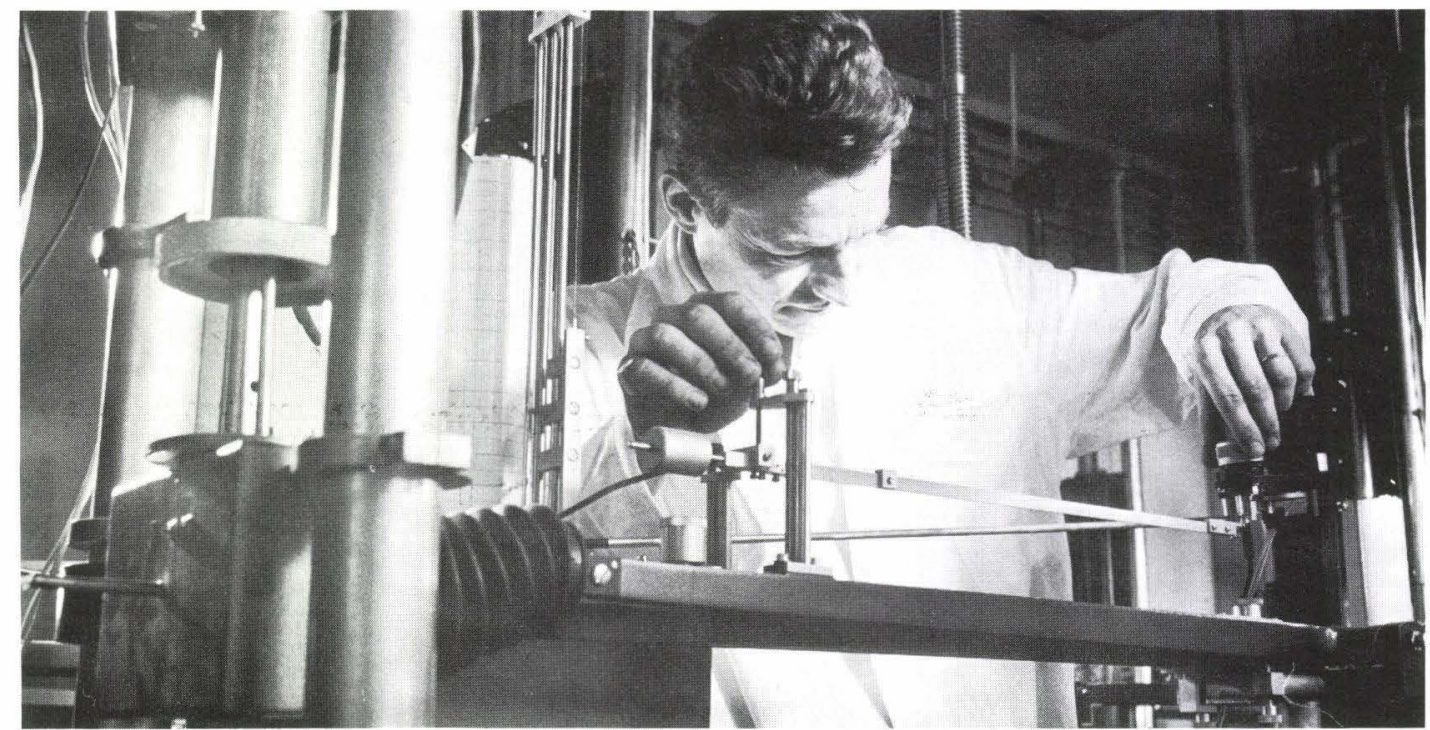

The metallurgical laboratories at Ispra, Italy.

\section{How Euratom research is carried out}

Euratom undertakes its research 'directly' in its own joint research centre (four establishments), which supplements the work being performed in member countries, or 'indirectly' -by public and private concerns in member countries under contracts for specific projects or 'association contracts' for joint research with national centres or undertakings.

-by joint research or exchanges of information with non-member countries: with the USA, Canada and the UK or through the projects of the European Nuclear Energy Agency (ENEA). 


\section{program launched}

\section{Joint research in Euratom centres}

Euratom's Joint Research Centre, with its four establishments, is the main instrument in the Community's drive to supplement national research programs.

\section{Ispra, Italy}

1,250 of Euratom's research staff work at Ispra, 30 miles north of Milan on Lake Maggiore. This, Euratom's largest research establishment, has been taken over from the Italian authorities.

The ORGEL project is Ispra's main concern (see page 18). But research there also covers numerous other fields including that of the Scientific Information Processing Centre (CETIS), equipped with electronic brains capable of, among other things, automatic documentation and translations and calculations required for reactor research. Apart from the ORGEL installations, Ispra is also equipped with a $5 \mathrm{~mW}$ heavy water-moderated and cooled research reactor.

\section{Geel, Belgium}

Geel, (near the Belgian research centre at Mol), is the location of the Central Nuclear Measurements Bureau. Its task is to carry out research in the field of nuclear measurements: studies on the improvement and enforcement of standards for the nuclear industry, and the development of instruments and measuring methods. The CNMB equipment includes a van de Graaff accelerator, a powerful linear accelerator and a laboratory for the preparation of samples.

The Bureau represents the Commission and member countries on the American-European Nuclear Data Committee, set up by Euratom and the OEEC. This Committee is the first example in the nuclear field of all the Western countries collaborating to marshal their combined resources. There will eventually be 180 staff at work here.

\section{Karlsruhe, Germany}

Euratom is building alongside the German Karlsruhe research centre the European Transuranian Institute. It will specialise in the study of plutonium and 'heavier than plutonium' (transuranian) elements, in particular plutonium fuel elements. Plutonium is potentially a first-class nuclear fuel, but its use in power reactors still presents technical problems. In particular, it is a suitable fuel for fast breeder reactors and the work at Karlsruhe will be closely linked with the fast reactor program. The staff here will eventually number 300 .

\section{Petten, Holland}

The Petten establishment is on the Dutch coast, 40 miles northwest of Amsterdam. Like Ispra a 'general competence' centre, much of the research will concern the testing of materials in the high-flux materials testing reactor built by the Dutch and handed over to Euratom. This reactor will test the behaviour of materials used in the construction of an atomic reactor. It will also be closely linked with the high-temperature gas-cooled reactor program (see page 20).
The German reactor at Karlsruhe.

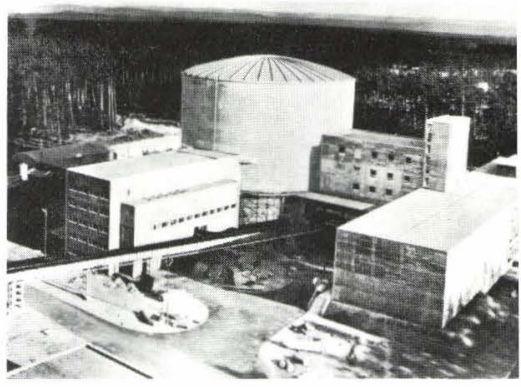

Materials testing reactor at Petten.

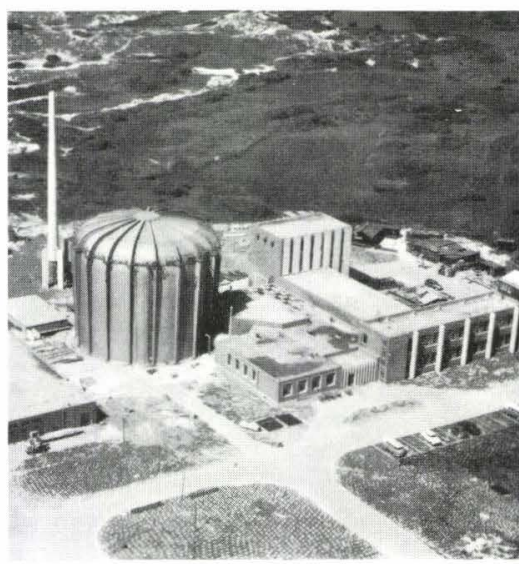




\section{Some of the subjects of reactor research}

Fuel elements

Moderators

Coolants

Reactor design and operation

Power production

Radioactive materials fuel elements are manufactured from natural uranium, in which the fissile element uranium 235 represents only one part in 139 , enriched uranium (i.e. the proportion of fissile U235 has been artificially increased), uranium $\mathrm{U} 233$ produced from thorium, and plutonium, a by-product of the fissile process.

these materials are used to slow down the fast neutrons released in nuclear fission. Water, heavy water, graphite and the expensive metal beryllium are among the moderators on which research is taking place. Fast reactors do not use a moderator to slow down neutrons. The neutrons are captured by a blanket of natural uranium, thus producing plutonium.

a wide range of substances, including gas, water, organic liquids and liquid metals.

studies of the physio-chemistry of reactors (e.g. the effects of heat and irradiation on materials used in construction); the control of reactor operation, the study of nuclear reactors.

comparative studies of the merits of different species of reactor.

including the chemistry and metallurgy of plutonium, the treatment and recuperation of fissile materials irradiated in reactors and the treatment of radioactive waste.

\section{In quest of economic reactors}

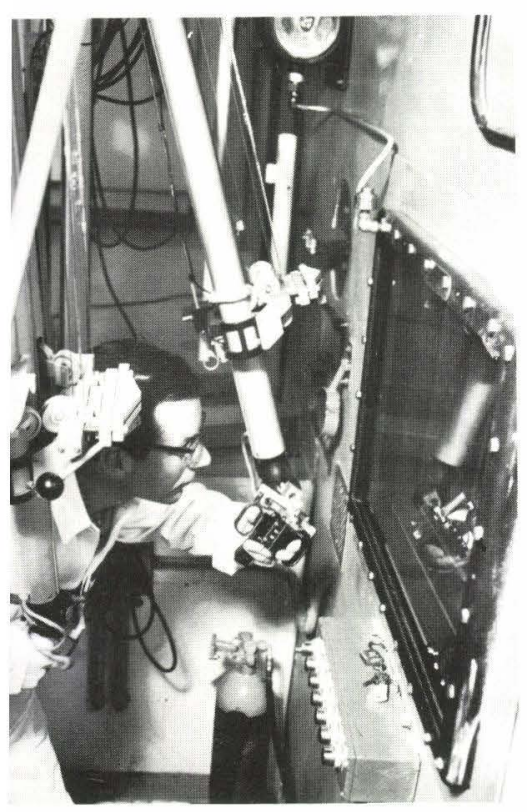

Remote handling of highly irradiated materials in a hot cell at Ispra.
A number of reactors of the two basic kinds - water-cooled and gas-cooled - are being installed in the Community. None will be wholly competitive with conventional power stations, but competitivity is not far away. Euratom is undertaking three types of research for cheaper power: improving on 'known' reactor types, the development of new reactor systems, and thermonuclear fusion. Euratom's reactor research is taking place both in the Joint Research Centre and under contracts.

\section{Orgel: a heavy-water reactor experiment}

Orgel is the centre-piece of research at Ispra. Much is known in the Community about the potentialities of heavy water-cooled and moderated reactors, and France has a $80 \mathrm{~mW}$ heavy watercooled power station under construction. But the use of an organic liquid as coolant opens up new possibilities, owing, largely, to its high boiling point. Moreover, heavy water reactors in general offer the advantage of being able to use natural uranium, sources of which are relatively plentiful, as fuel. The ORGEL equipment at Ispra includes a critical assembly, 'ECO' and an experimental reactor for the testing of materials 'ESSOR' (ESSai ORgel) is being built. 


\section{International research projects}

\section{Euratom's technolo-}

gical progress depends

to a large extent on

the experience which

can be gained outside

the Community, either

through joint projects with the other member countries of the European Nuclear Energy Agency (ENEA), or through bilateral agreements with third countries.

The 'DECA' apparatus for fusion research at Fontenay-aux-Roses, France.

\section{0 research}

\section{contracts}

\section{Fast reactors}

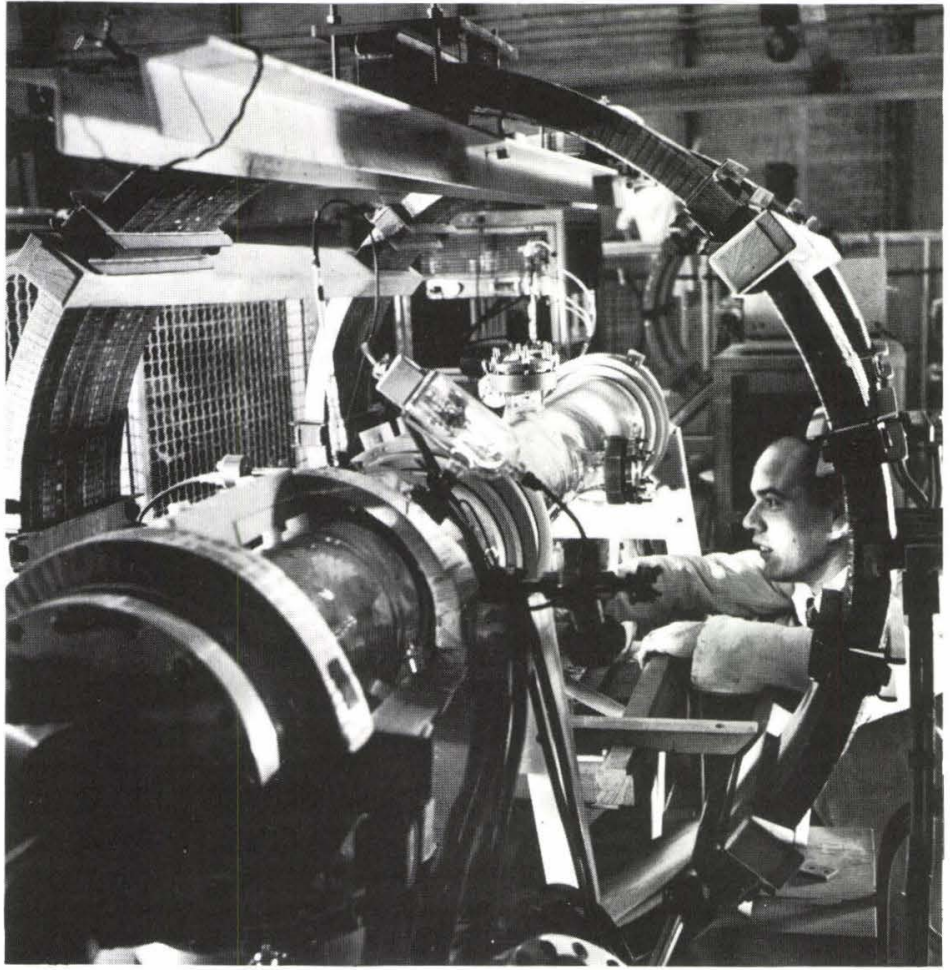

Much of Euratom's research work is being carried out under contracts with national research centres or public or private industrial undertakings, and more than 400 such contracts are under way. Around twenty of these are long-term and large-scale 'association contracts' under which Euratom and a national undertaking contribute staff to joint research teams and funds to a budget administered jointly. Most of Euratom's research on fast reactors, fusion, ship propulsion and biology is being performed under association contracts. The rest of the contracts are short-term and smaller assignments under which national undertakings perform work on Euratom's behalf. They give a valuable stimulus to the Community's developing nuclear industry.

Over the longer term this is perhaps the most promising field of research of all and the 1963-67 research program is devoting more money to it than to any other. By 'breeding' plutonium, which can later be used as a fuel, at the same time as heat is being produced from the fission process, fast breeder reactors can produce as much or even more fuel than they consume. There are still, however, important obstacles to be overcome before these reactors are capable of large-scale power production. Euratom's fast reactor research is being performed under association contracts. Under one, with the French CEA, Euratom is participating in the construction and operation of the 'Rapsodie' reactor at the French Cadarache Centre. A second is with the German KBB organization at Karlsruhe. A third planned with the Italian authorities. In this way, Euratom will be a partner in each of the main fast reactor projects in the Community. 
'Proved' reactors

\section{High-temperature} reactors

\section{Other reactor types}

Nevertheless, there is still scope for improving on types of reactors already developed and producing power. Much of Euratom's work falls within the scope of the US-Euratom Agreement (see page 22) under which the two sides contribute up to $\$ 50$ million each for joint research centred on water-cooled reactors, the type being installed under the power programs. By mid-1963 the two sides had engaged over $\$ 30$ million for research under some 130 contracts in Europe and the USA. The research covers such subjects as the improvement of fuels and materials, the recycling of plutonium and the treatment of radioactive waste.

Euratom represents its member countries in the European Nuclear Energy Agency's 'Dragon' high-temperature gas-cooled reactor project, contributing $46 \%$ of the total cost over an 8-year period. Of the 200 or so staff at work on the project, some 35 are from Euratom. The 'Dragon' reactor will be completed early in 1964. Operating at a much higher temperature than 'Calder Hall' reactors (with a gas outlet temperature of $750^{\circ} \mathrm{C}$ instead of $350^{\circ} \mathrm{C}$ ) and using a novel form of fuel element incorporating thorium as well as enriched uranium, 'Dragon' offers prospects of important reductions in power costs.

A sister project is the German BBC-Krupp 'pebble-bed' reactor, now being built at the Jülich centre. Euratom intends to participate in this project under an association contract. The co-ordination of certain technical aspects of the two projects will be a task of the Petten establishment.

Among other types of reactors being studied are the SUSPOP homogeneous suspension reactor under association contract with the Dutch KEMA laboratory (the fuel is suspended in a liquid moderator) and the so-called ' fog' $^{\prime}$ reactor using a mixture of water and vapour as coolant. Another experiment,

Interior of EL3 research reactor, Saclay, France.

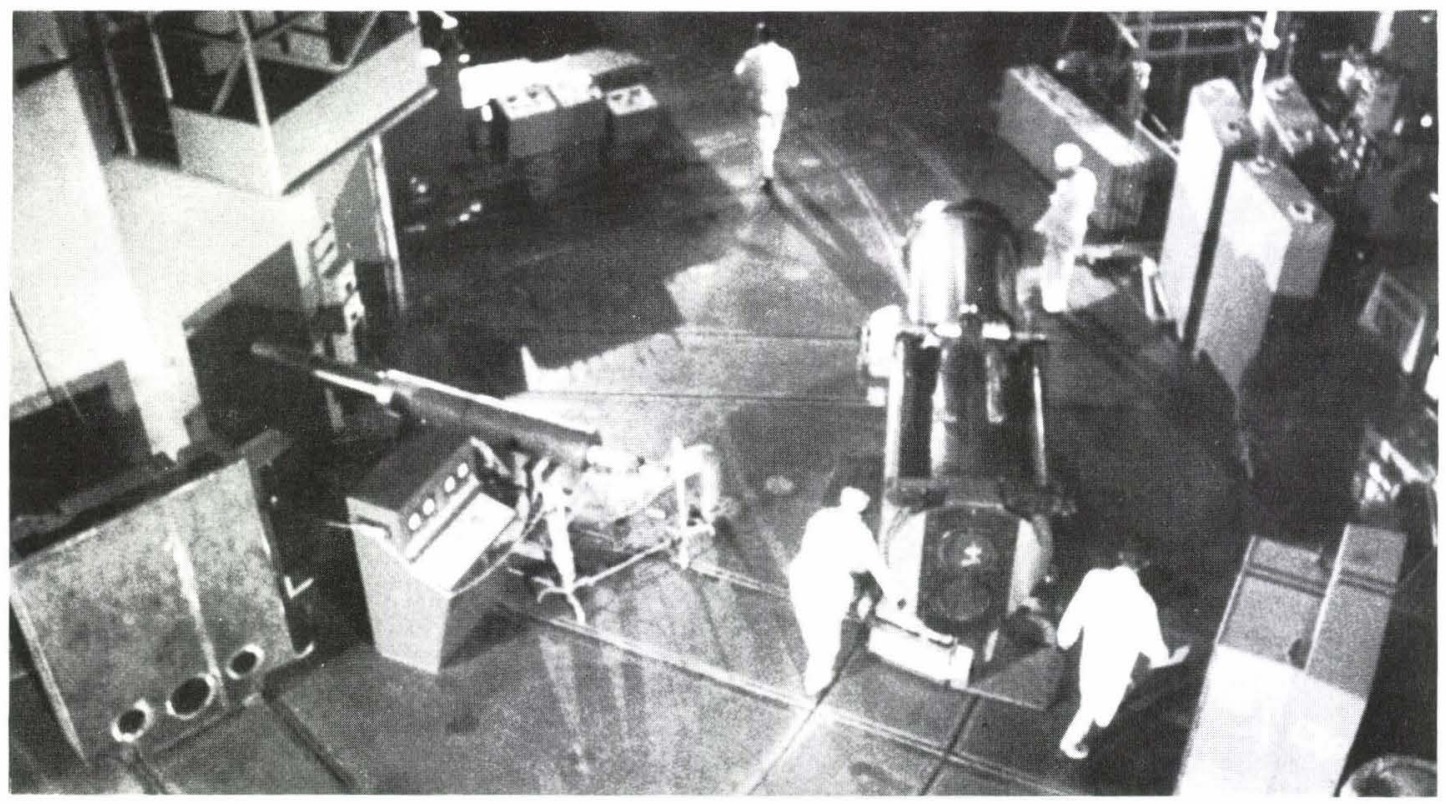


now nearing conclusion, is the ENEA Halden reactor. This reactor was originally built for the Norwegian Atomic Energy Institute to study the problems of operating boiling heavy water reactors. Here again, Euratom is representing the member countries financially and in the contribution of personnel.

BR2: powerful material's testing reactor
As well as the Petten reactor (see page 17), Euratom has at its disposal the most powerful materials testing reactor in Europe and one of the most powerful in the world. This is the BR2 high-flux materials testing reactor which Euratom is operating jointly at the Belgian Mol centre with the Belgian authorities over a 20 -year period. This $50 \mathrm{~mW}$ reactor, possessing a very high neutron flux, is extremely flexible and permits a large number of irradiation experiments to take place simultaneously and to start and end without interfering with each other. BR2 is a valuable asset for the testing of materials for use in the construction of reactors. 44 Euratom staff are at present at work on BR2 and associated experiments.

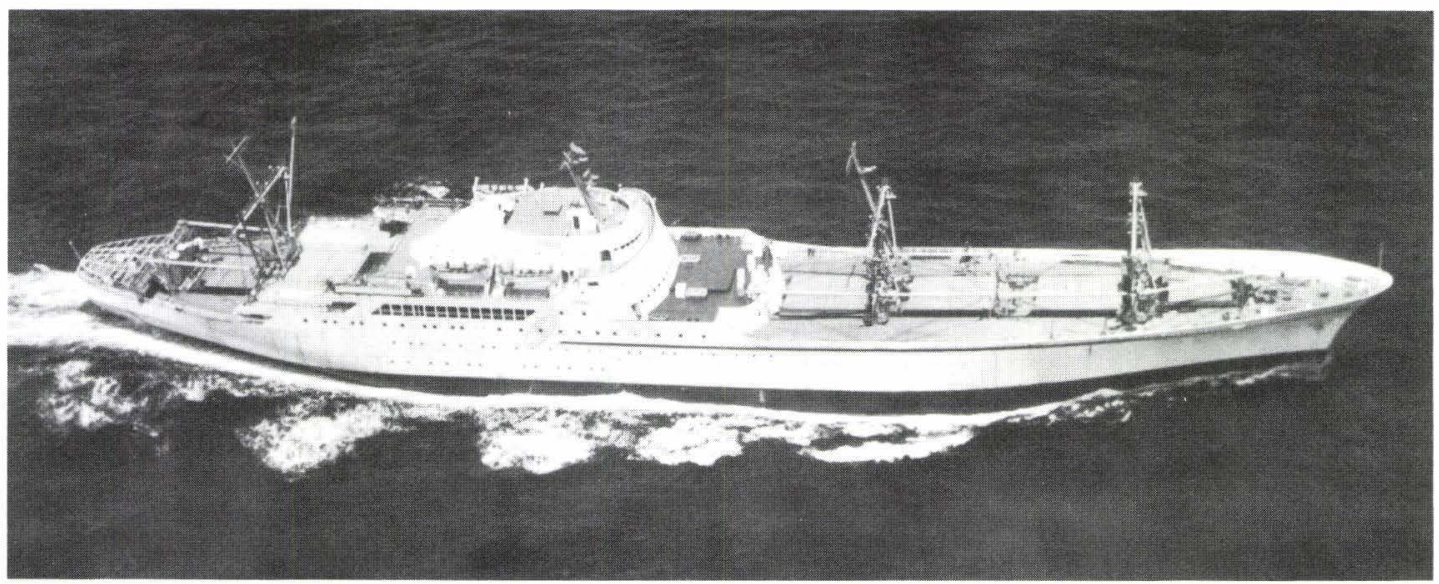

The world's first nuclear-propelled cargo ship, USS Savannah.

Atomic energy can also be used for propelling ships. It is not yet economic, however, to do so and Euratom is therefore participating in the development of reactors specially designed for ship propulsion. The Commission has signed four association contracts with research groups: two in Germany and one each in Italy and Holland, with Euratom contributing research staff and a substantial part of the study costs.

One project is for a reactor for a merchant ship, in which Euratom is working in partnership with German shipbuilding and nuclear groupings; another is a draft design for a nuclearpowered tanker in which the partners are two Italian companies; the third is the Dutch RCN's design study for an advanced pressurized water reactor for a merchant ship; and the fourth for general research into nuclear ship propulsion problems at the German Geesthacht Centre. Euratom has set up a Nuclear Marine Coordinating Committee, consisting of representatives from the projects, the governments and Euratom, to prevent unnecessary duplication of work. 
Thermonuclear

fusion: long-term

prospect of

unlimited power
So, far, the use of thermonuclear power - the power generated when atoms fuse, as compared with nuclear reactions in which they split up - has been limited to the $\mathrm{H}$-bomb. The possibilities of harnessing its enormous potential for peaceful purposes are now being studied in all the leading atomic countries, though there is still a long way to go before a thermonuclear power station can be built. A major handicap is that fusion can only take place when the ionized gas (known as plasma) is heated to a temperature of tens of millions of degrees Centigrade.

Euratom is linked with virtually all the European projects for the peaceful application of fusion. Five association contracts are in course. These are with the French CEA for a large-scale project at the Fontenay-aux-Roses centre near Paris, with the Italian CNEN centre at Frascati, with the German Institut für Physik und Astrophysik (associated with the Max Planck Institut) at Munich, with the Dutch FOM Institute at Jutphaas and with the German Jülich centre. Close links between the various projects are assured by a liaison committee bringing together physicists from the various laboratories.

\section{Bilateral agreements}

On November 8, 1958 Euratom and the USA signed an agreement for a joint power station program (see page 20) and a joint research and development program under which the two sides are contributing up to $\$ 50$ million. Research projects are invited from Community and American firms which are evaluated by a Joint Research and Development Board. By mid-1963 more than 130 research contracts had been approved and were being executed in the Community and the USA. The research is concerned mainly with the improvement of water-cooled reactors, the study of means of improving reactor fuel and the recycling of plutonium. This agreement represents an atomic partnership in which the two sides are jointly developing the use of nuclear power.

This agreement was signed on February 4, 1959, and covers the exchange of information and training facilities and sets up two committees to administer the co-operation: a political-level Continuing Committee meeting once a year and a technical-level Joint Working Group meeting a number of times a year. Apart from exchanges of information in research and other fields, exchanges of personnel have been arranged: Euratom scientists have been working at Harwell and British scientists have been working at the BR2 reactor at Mol. The UK is also supplying fissile materials for Community research reactors. Among the subjects on which information exchanges have taken place are fast breeder reactors, fusion, health and safety problems, nuclear ship propulsion and fuel retreatment. 
Euratom and British technicians at work on the 'Dragon' project.

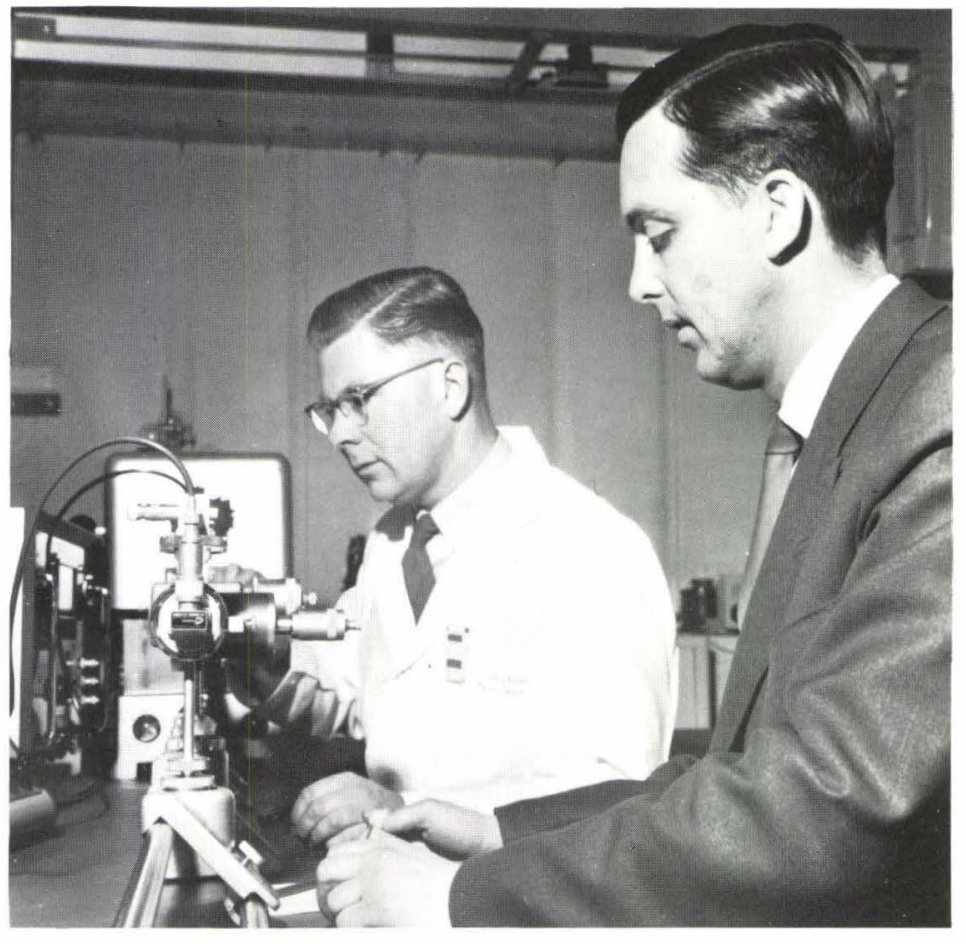

Agreements signed on October 6, 1959, cover joint research on the natural uranium heavy water-moderated reactors, of which the Canadians have wide experience. They provide for a 5-year joint research and development program (with each side contributing up to $\$ 5$ million) a joint advisory committee and the exchange of information.

Agreements signed on June 9, 1961 and September 9, 1962 respectively provide for co-operation over a wide field of activities, including the exchange of research information and the improvement of prospective techniques for raw materials. 


\section{Radiation and isotopes at work}

The effects of ionizing radiation* and of the applications of radioactive isotopes are of great consequence for industry and agriculture. Isotopes have made possible many scientific discoveries, some of which may prove as important as those which followed the invention of the microscope. Euratom is actively encouraging development in this field.
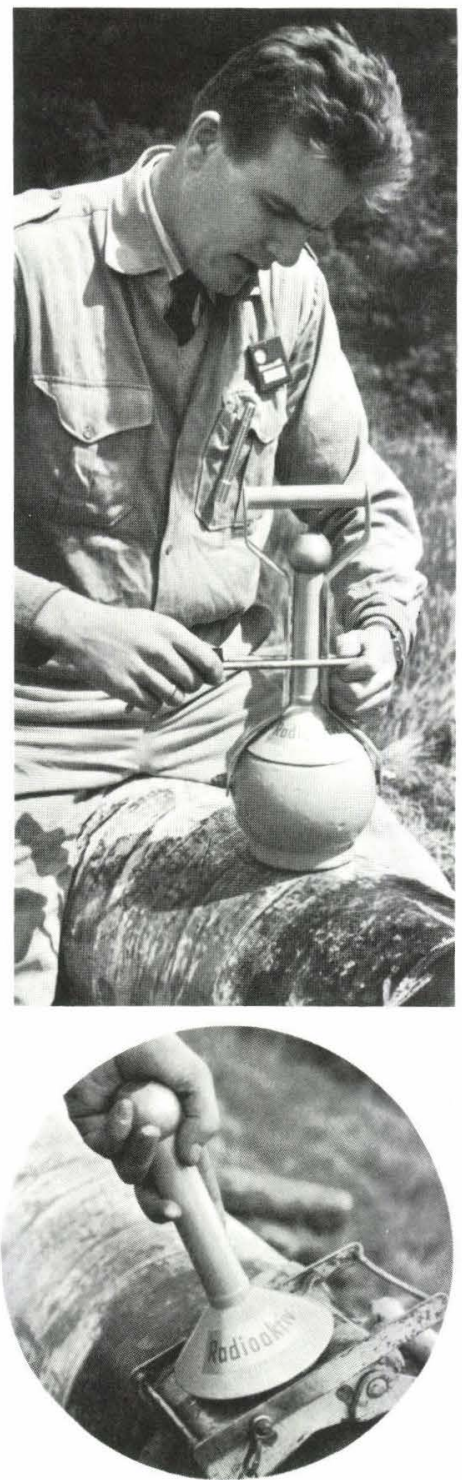

Radioisotopes being used to check pipeline.

\section{Vegetable and animal radiobiology}

Certain minerals, such as radium and uranium, as well as certain artificial products (radioactive isotopes) emit ionizing radiation. According to the extent of the dose, these can be either beneficial or dangerous for the human organism. Euratom has signed a contract with the Dutch 'Organisatie Toegepast voer Natuurwetenschappelijk Onderzoek' (TNO) for a study of the physiological disorders due to radiation in animals. Research for Euratom is also being undertaken on the use of radio-elements in agriculture under an association contract with the Dutch MAC Institute at Wageningen, where a special reactor has been built.

\section{Innovations in medicine}

Cooperation with doctors and physiologists to widen the medical applications of radioisotopes and ionizing radiation is also a concern of Euratom. In medicine, radioisotopes are being used in therapy and diagnosis, to localize tumours, and to provide information on the functioning of certain organs. Research is being undertaken into the effects of radiation on human genetics under an association contract with the Naples Genetical and Biophysical Institute.

\section{Industry and agriculture}

Radioactive isotopes (manufactured in atomic installations) have been of great value to agriculture, particularly in furthering the efficient use of fertilizers. They have also helped Australian sheep-farmers by drawing their attention to the need for copper salts in the diet of sheep if the quality of their wool is to be improved. In addition, ionizing radiation can be used in preserving perishable foodstuffs.

It is in industry, however, that radioactive isotopes are most widely used. Examples are: control of the thickness of sheets of paper or cardboard during manufacture, the study of the wear and lubrication of machinery, the sorting and preparation of minerals and the location of blockages in pipelines. According to one estimate, radio-elements save the US economy about $\$ 500$ million a year.

* Radiation, such as alpha, beta and gamma rays, causes ionization in the materials through which it passes. Ions are the particles which constitute an electrical charge. 


\section{Pooling the results of research}

\section{The Information and Documentation}

\section{Centre}

Euratom's Information and Documentation Centre gathers atomic research information from all over the world, classifies and stores it and makes it available to Community researchers and industrialists, along with the results of Euratom's own research efforts.

The Centre runs libraries at the headquarters and the research establishments, distributes reports on Community research and produces a number of periodicals on atomic matters. One of these is the Transatom Bulletin, which indexes and circulates each month information on existing and planned translations from Slavonic and Oriental into Western European languages. Many of the publishing activities are carried out in close co-operation with the British and American nuclear authorities: for instance, the American Nuclear Science Abstracts may reprint any article appearing in Euratom publications, while Euratom receives directly a copy of all abstracts to be published in English.

The Centre runs a comprehensive documentation service, which is being equipped with a computer, while a section of the research department at Ispra (CETIS) is working on the complete automation of information storage and recall. CETIS is equipped with IBM 7090 and 1401 computers and is the bestequipped documentation research group in Europe.

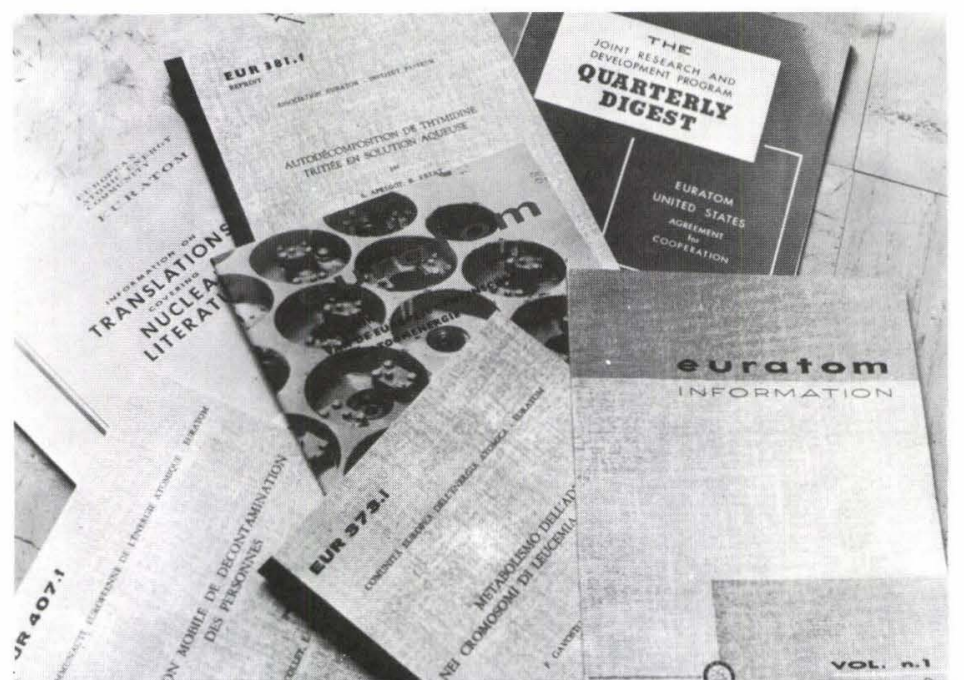

It is essential

that the

Community's

research workers

and technicians

have easy access to

the results of

Community research

and to published

nuclear information

from elsewhere

in the world.

\section{Euratom's Information}

and Documentation

Centre provides

for the Community

an information and

documentation

service of which

increasing use is

being made by

individuals, firms

and national

organizations. 


\section{The Supply Agency}

Euratom must ensure, through its supply policy, that all consumers in the Community have equal access to supplies of raw and fissile materials, and that adequate amounts of these materials are available for the Community's nuclear industry. These tasks are the responsibility of the Supply Agency.

The Agency came into being on June 1, 1960; it comes directly under the control of the Commission, and operates on a commercial basis. It has an option on all raw and fissile materials produced in the Community and the exclusive right to make purchase or sales contracts outside the Community. All fissile materials are in fact the legal property of the Community and the Agency is responsible for their use. Exercising its right of option, the Agency may build up its own stocks of other nuclear materials and sell them to consumers. But, owing to the present excess in world supplies of uranium ore, the Agency's rôle here is limited to that of 'broker' bringing supplies and consumers into contact. Consumers inform the Agency of their requirements and producers indicate the materials they have on offer; the Agency informs potential customers of the conditions of offers at hand. The Agency has concluded a number of contracts for the supply of fissile materials for research and power reactors both within and outside Euratom programs. Lastly, it has undertaken a market survey concerning the supply of nuclear materials for the 1963-67 period.

\section{Euratom's inspectors}

Euratom must keep a close watch on the use of nuclear materials and equipment in the Community, and above all on fissile materials. Moreover, each of Euratom's agreements with third countries stipulates that materials supplied to Euratom should be used only for non-military purposes. All enterprises therefore have had to report on the equipment of their installations and have to make regular declarations to the Commission of stocks, transfers and transactions of nuclear materials.

To ensure that declarations are being correctly made, Euratom maintains an inspection team, whose job it is to visit installations and to undertake physical and accountancy checks on the materials held. Enterprises which fail to carry out their obligations are liable to various types of penalty, including, in the last resort, the denial of access to fissile materials. Euratom's security control system is the first ever to have legal force over a number of nations. Other international organizations the International Atomic Energy Agency of the United Nations and the OEEC - have drawn up control rules; but these are not binding on governments unless they are either receiving aid or are submitting themselves to supervision voluntarily. Euratom's control system is thus an important step forward in the voluntary submission of national states to international rules.

\section{The nuclear common market}

\section{No frontiers for the atom}

International trade barriers are out of the question for the Community's atomic industry. Since the end of 1958, Euratom has been a common market for nuclear materials and equipment: there are no trade barriers between member countries, nor can any be introduced. A common market also means a common trade policy towards non-member countries and a single tariff. Euratom has no tariff on raw or fissile materials, and, although there is a tariff on most items of equipment, this has been reduced or suspended for a three to five years period from 1962.

\section{Free movement of labour and capital}

Similarly, restrictions on employment on grounds of nationality have no place in the Community. The Treaty stipulates that there must be freedom for qualified nuclear workers from member countries to take employment anywhere in the Community. A plan to this effect has been prepared and was approved by the Council of Ministers in March, 1962. The Euratom Treaty also provides for free movement of capital, though in fact no important obstacles have so far been encountered. 


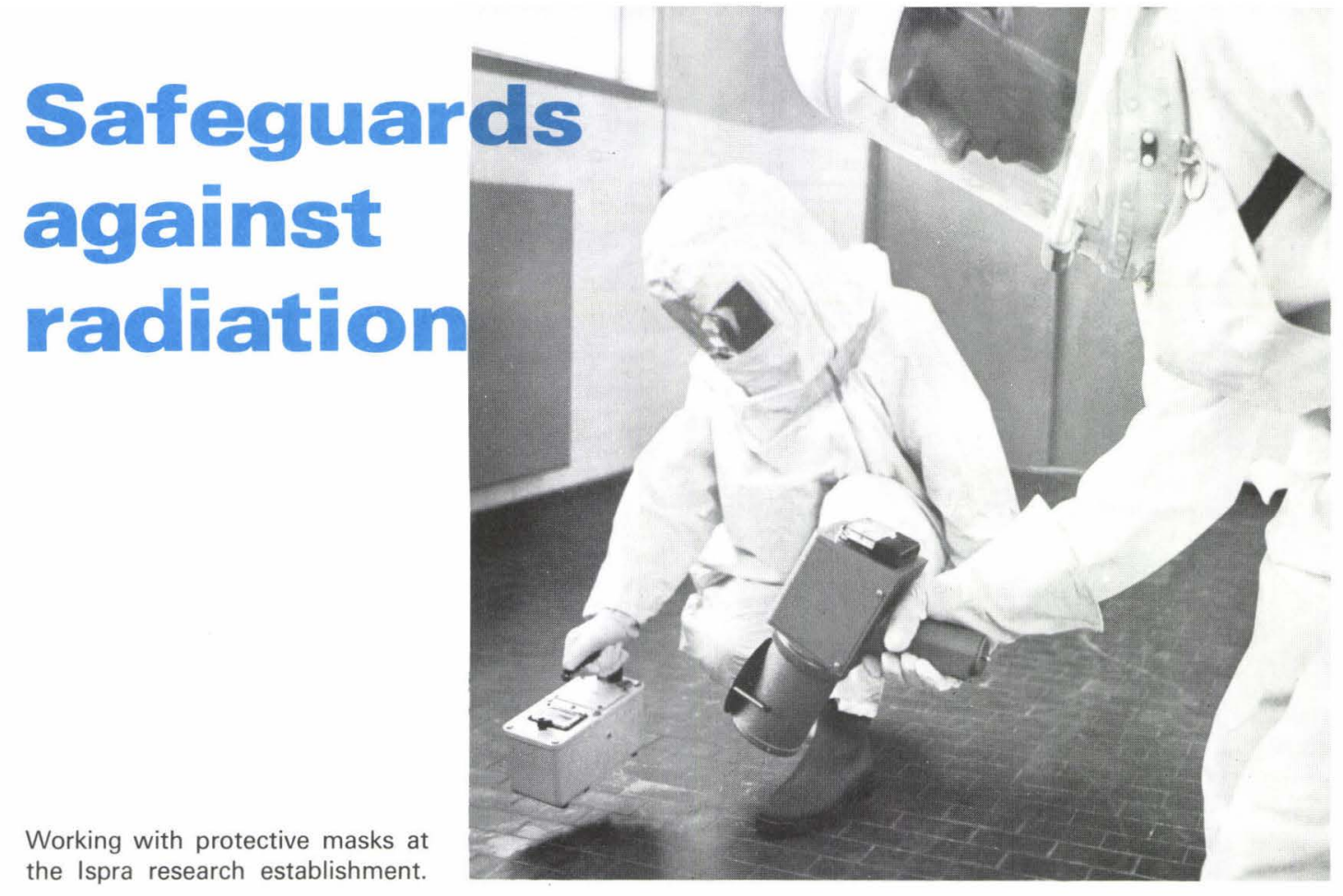
the Ispra research establishment.

A-bomb and $\mathrm{H}$-bomb explosions warned the world of the dangers of radiation. Nuclear energy could also be a potential danger to the health of workers and the population at large when used for peaceful purposes. Nor do the dangers of radioactivity stop at frontiers. Negligence in one country could jeopardize the health and lives of people elsewhere. The need for international legislation and for its strict enforcement by national governments is crystal clear.

\section{Bringing safety \\ rules into line}

\section{Control of \\ radioactivity}

\section{Safety in nuclear installations}

Euratom is co-ordinating national nuclear legislation by insisting on the application of certain basic rules to protect workers and the public from radiation dangers. In February, 1959, the Council of Ministers approved the Basic Health Standards, which the six Governments are obliged to incorporate in their future nuclear health legislation. These standards, which are already being fully applied under the German atomic law and are at various stages of incorporation into the national legislation of the other Community countries, are the first international nuclear safety laws to be binding on governments.

Euratom keeps a close watch on radioactive contamination of the air, sea water, drinking water and soil by indexing and classifying reports received from the monitoring posts of national authorities and by sending its own specialists to check on the work done at these posts. Euratom is also making special studies of radioactivity in some of the Community's large rivers and in the atmosphere.

Lastly, new projects for nuclear installations must be submitted for the Commission's opinion, the latter examining them from the standpoint of health and safety. A watertight procedure obviates any possibility of loopholes in these examinations. 


\section{TWO revolutions in ONE}

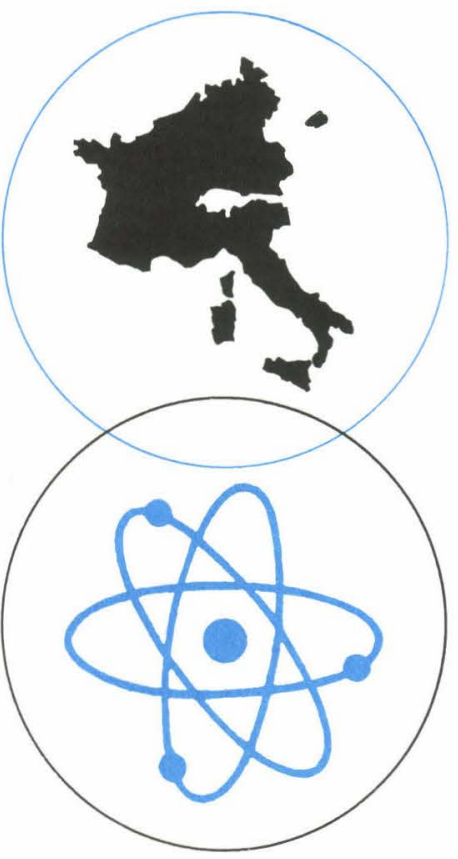

Euratom is the spearhead of the nuclear revolution in the Community. Countries which have fought each other time and again through the centuries, and who only seventeen years ago were locked in a cruel and destructive war, have pooled their resources to exploit the peaceful development of nuclear energy. Together they will enter the industrial revolution which nuclear energy is bringing.

For in Europe the nuclear revolution is part of a political revolution which is no less important. The countries of the European Community have abandoned the resort to force and opted for unity. Euratom harnesses the atomic revolution to the peaceful political and economic revolution; together, they are changing the face of Western Europe.

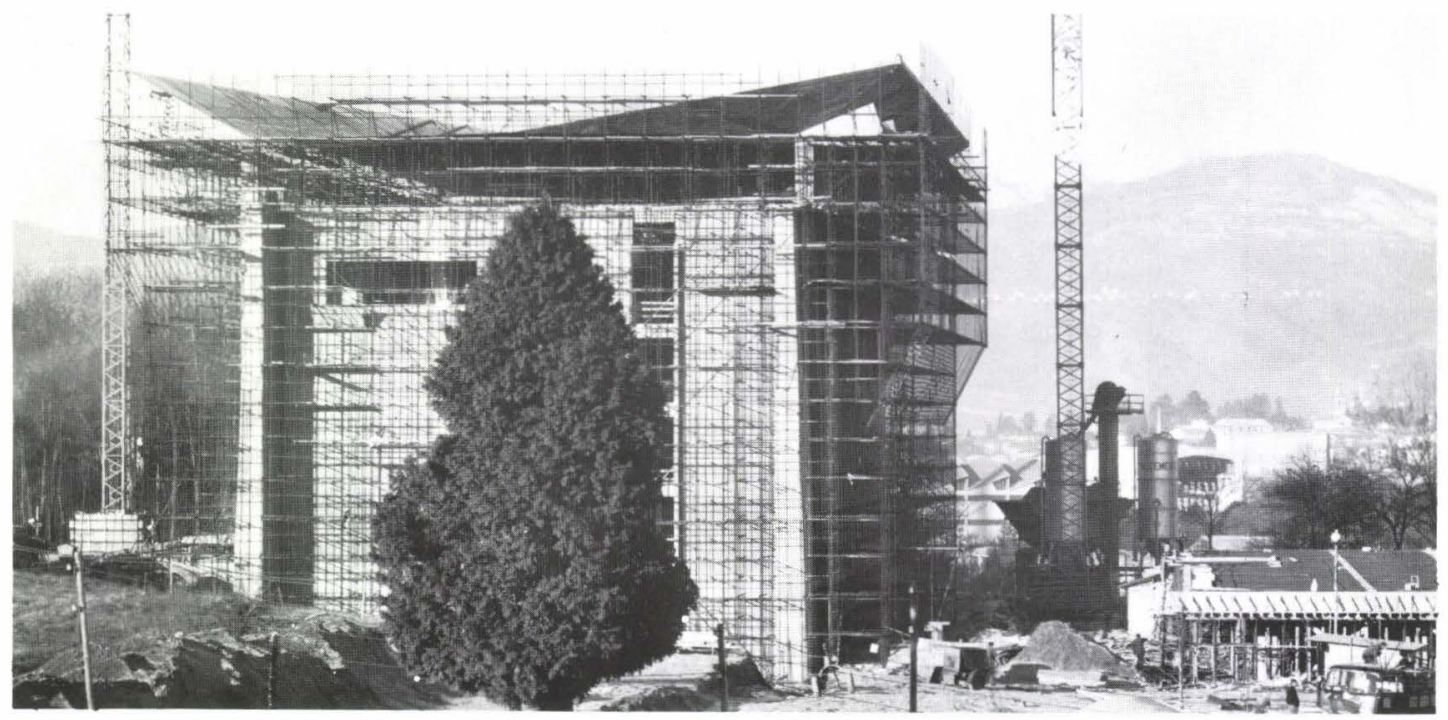

Above: Under construction at Ispra. The building to house the ECO critical assembly.

Right: The Marcoule reactors in Provence, the first in the Community to supply electricity to a national network. 


\section{For further information}

Euratom

Official Spokesman
Euratom Commission, 51-53, rue Belliard, Brussels Telephone: 13.40 .90
France

Germany

Italy

Netherlands

United Kingdom

United States
Bureau d'Information des Communautés Européennes

61, rue des Belles-Feuilles, Paris $\left(16^{\circ}\right)$. Téléphone: Kléber 53.26

Presse- und Informationsstelle der Europäischen Gemeinschaften Bonn, Zitelmannstrasse 11. Telephone: 2.60.41

Ufficio Stampa e Informazione delle Communità Europee 29, via Poli, Rome. Telephone: 670.696/688/182

Voorlichtingsdienst van de Europese Gemeenschappen Mauritskade 39, The Hague. Telephone: 184.815

European Community Information Service

23, Chesham Street, London SW1. Telephone: Belgravia 4904

European Community Information Service

Farragut Building, Farragut Square, Washington 5, D.C. Telephone: Washington 296.5131.

\section{"European Community Press and Information Service}

Brussels

Luxembourg
Press and Information Service of the European Communities 244, rue de la Loi, Brussels. Telephone: 35.00 .40

Press and Information Service of the European Communities

18, rue Aldringer, Luxembourg. Telephone: 292.41 


\section{Othèr publications}

\section{Euratom}

illustrated brochure

\section{Europe 235}

pictorial brochure based on shots from a film (French and German only)

\section{The Euratom Bulletin}

quarterly Bulletin (subscription: UK. $18 /-$, US $\$ 3.50$ a year) spotlighting different aspects of the peaceful applications of nuclear energy; intended for all those interested, even indirectly, in the peaceful applications of nuclear energy. Specimen copies may be obtained from: Dissemination of Information Directorate, Euratom Commission.

Subscriptions: A. W. Sijthof, Postbox 26, Leiden, Netherlands.

\section{Euratom's second five-year research} program 1963-67 (Community Topic no. 7)

\section{The Annual Reports}

for the six years 1958-63

Report of the position of the nuclear industries in the Community (1958)

\section{The Euratom Treaty}

\section{European Community}

(a monthly magazine published in London and Washington) 
1

\section{european community information service}

